\title{
ANALISA DAN PERANCANGAN SISTEM INFORMASI PENDAFTARAN PASIEN RAWAT JALAN BERBASIS WEB PADA RUMAH SAKIT RAWAMANGUN
}

\author{
Dian Gustina, Ruri Puji Novianti \\ dgustina@yahoo.com
}

\begin{abstract}
ABSTRAK
Teknologi komputer zaman era globalisasi sekarang ini sangatlah pesat, hal tersebut digunakan dalam sebuah sistem informasi yang memanfaatkan teknologi komputerisasi yang berbasis web. Teknologi tersebut dapat memudahkan kita untuk melakukan pengolahan data dan tentunya dapat menghemat waktu, ruang, dan biaya. Dan hasil suatu informasi yang diperoleh akan sangat memuaskan, berguna dan bermanfaat dari suatu lembaga atau instansi yang menggunakannya. Pengolahan data dan informasi secara cepat, tepat dan efisien adalah hal penting yang dibutuhkan bagi lembaga atau instansi, yaitu salah satunya adalah bidang kesehatan. Pada penulisan ilmiah ini penulis membahas penggunaan PHP sebagai bahasa yang mendukung website sebagai informasi yang dinamis dan dapat dikelola dengan mudah dan dapat memberikan informasi yang akurat dan efektif. Penulis juga menggunakan database $M y S Q L$ sebagai database. Pembuatan Web Medical Check Up diharapkan dapat membantu tamu dalam memesan kamar melalui internet tanpa harus datang langsung ke rumah sakit. Dan tidak takut kesalahan informasi yang diterima oleh pihak rumah sakit tentang data yang diberikan oleh pasien. Pasien juga dapat mendapatkan informasi rumah sakit yang selalu terupdate hanya dengan terhubung internet. Dan juga manager dapat melihat kemajuan rumah sakit secara detail dengan hanya melihat laporan yang dapat di print setiap saat. Dan Admin mudah sekali dapat melakukan segala update data-data rumah sakit yang ada untuk kebutuhan dan pemeliharaan kesehatan ke depannya.
\end{abstract}

\footnotetext{
ABSTRACT

Computer technology era of globalization today is very rapid, it is used in an information system that utilizes computerized web-based technology. The technology can facilitate us to perform data processing and of course can save time, space, and cost. And the results of an information obtained will be very satisfactory, useful and useful from an agency or agency that uses it. Processing data and information quickly, precisely and efficiently is important thing needed for institution or institution, that is one of them is health field. In scientific writing, the writer discusses the use of PHP as a language that supports the website as dynamic information and can be managed easily and can provide accurate and effective information. The author also uses the MySQL database as the database. Making Medical Check Up Web is expected to help guests in ordering rooms via the internet without having to come directly to the hospital. And not afraid of misinformation received by the hospital about the data provided by the patient. Patients can also get hospital information that is always updated simply by connecting the internet. And also the manager can see the progress of the hospital in detail by just looking at reports that can be printed at any time. And Admin is very easy to do any updates of existing hospital data for the needs and health care in the future.
} 


\section{PENDAHULUAN}

Perkembangan teknologi komputer zaman era globalisasi sekarang ini sangatlah pesat, hal tersebut digunakan dalam sebuah sistem informasi yang memanfaatkan teknologi komputerisasi yang berbasis web. Teknologi tersebut dapat memudahkan kita untuk melakukan pengolahan data dan tentunya dapat menghemat waktu, ruang, dan biaya. Dan hasil suatu informasi yang diperoleh akan sangat memuaskan, berguna dan bermanfaat dari suatu lembaga atau instansi yang menggunakannya. Penggolahan data dan informasi secara cepat, tepat dan efisien adalah hal penting yang dibutuhkan bagi lembaga atau instansi, salah satunya adalah dalam bidang kesehatan.

Sebagai salah satu pelayanan kesehatan masyarakat adalah rumah sakit, sudah seharusnya mempunyai sistem informasi yang cepat dan akurat untuk memenuhi kebutuhan akan informasi tersebut secara cepat, akurat, dan tepat waktu. Maka dibutuhkan suatu sistem program aplikasi data berbasis komputer yang andal. Rumah sakit rawamangun yang dalam hal ini bergerak dalam pelayanan kesehatan masyarakat masih menemui kendala terutama dalam pengolahan data pasien yang melakukan rawat jalan masih dilakukan secara manual, akibatnya informasi yang tidak akurat, relevan sangat sulit didapat dan pelayanan kepada atau bagi pasienpun tidak dapat dilakukan semaksimal mungkin.

Untuk mengatasi permasalahan rawat jalan yang dilakukan secara manual, maka diperlukan suatu program pengolahan data pasien yang melakukan rawat jalan agar dapat dihasilkan laporan yang tepat dan akurat. Dalam hal ini untuk merancang sistem informasi data pasien pada Rumah Sakit Rawamangun digunakan aplikasi PHP, MYSQL dan Dreamweaver.

Tujuan dilakukannya solusi dalam mengatasi permasalahan dengan cara merancang program pengolahan data menggunakan aplikasi PHP, MYSQL, dan Dreamweaver pasien agar rumah sakit rawamangun bisa melakukan rawat jalan secara online atau berbasis web dan tidak lagi dengan cara manual. Sehingga pengolahan data pasien bisa dilakukan dengan akurat dan efisien.

\section{Metodologi Penelitian}

Metode penelitian merupakan suatu cara bagaimana seorang penulis dapat memahami suatu pembahasan, permasalahan dan pemecahan masalah di dalam sebuah sistem. Metode yang digunakan oleh penulis adalah metode OOP ( Object Oriented Programing ), metodologis yang terkenal yaitu Grady Booch, James Rumbaugh, dan Ivar Jacobson. Mereka mengkombinasikan metode-metode mereka untuk memperoleh notas-notasi yang dapat digunakan seluruh metodologi berorientasi objek yang dikemukakan para metodologis. Mereka membentuk notasi yang dapat digunakan bersama yaitu: Unified Modeling Language (UML).

Notasi UML terutama diturunkan dari 3 notasi yang telah ada sebelumnya, yaitu: Grady Booch OOD (Object-Oriented Design), Jim Rumbaugh OMT (Object Modeling Technique), dan Ivar Jacobson OOSE (Object-Oriented Software Engineering). Unified Modeling Language (UML) merupakan sistem arsitektur yang 
bekerja dalam OOAD (Object-Oriented Analysis/Design). UML merupakan bahasa pemodelan yang paling sukses dari tiga metode OO yang telah ada sebelumnya, yaitu Booch, OMT (Object Modeling Technique), dan OOSE (Object-Oriented Software Engineering). Metode penelitian yang dipakai oleh penulis adalah Object Oriented Analysis and Design (OOAD), yang terdiri dari :

1. Menganalisa masalah

2. Menggambarkan proses sistem

3. Identifikasi object

4. Spesifikasi atribut

5. Mendefinisikan Operasi

6. Komunikasi antar object

7. Desain aplikasi

8. Testing aplikasi

9. Implementasi aplikasi

\section{ANALISIS DAN PERANCANGAN}

\section{A. Business Use - case}

Use case adalah deskripsi dari sebuah sistem dari perspektif pengguna. Use case yang bekerja dengan cara mendeskripsikan tipikal interaksi antar user (pengguna) sebuah sistem dengan sistemnya itu sendiri melalui sebuah cerita bagaimana sebuah sistem yang akan dipakai (Munawar, 2005).

1. Business Use Case View, yang terdiri dari :
a. Use case menampilkan Home
b. Use case menampilkan Profile
c. Use case menampilkan Fasilitas
d. Use case menampilkan Jadwal Dokter

2. Business Use Case Transaction, yang terdiri dari :
a. Use case Pendaftaran
b. Use case Daftar Pasien
c. Use case Jenis Rawat jalan

d. Use case Jadwal Dokter

e. Use case Daftar Obat

f. Use case Diagnosa

g. Use case Pembayaran

h. Use case Pembelian Obat

i. Use case Admin

j. Use case Form Pasien

k. Use case Form Jenis Rawat Jalan

1. Use case Form Jadwal Dokter

m. Use case Form Daftar Obat

n. Use case Form Diagnosa

o. Use case Form Pembayaran

p. Usecase Form Pembelian Obat

q. Usecase Form Admin

r. Laporan Pasien

s. Laporan Jenis Rawat Jalan

t. Laporan Jadwal Dokter

u. Laporan Daftar Obat

v. Laporan Diagnosa

w. Laporan Pembayaran

x. Laporan Pembelian Obat

y. Laporan Admin

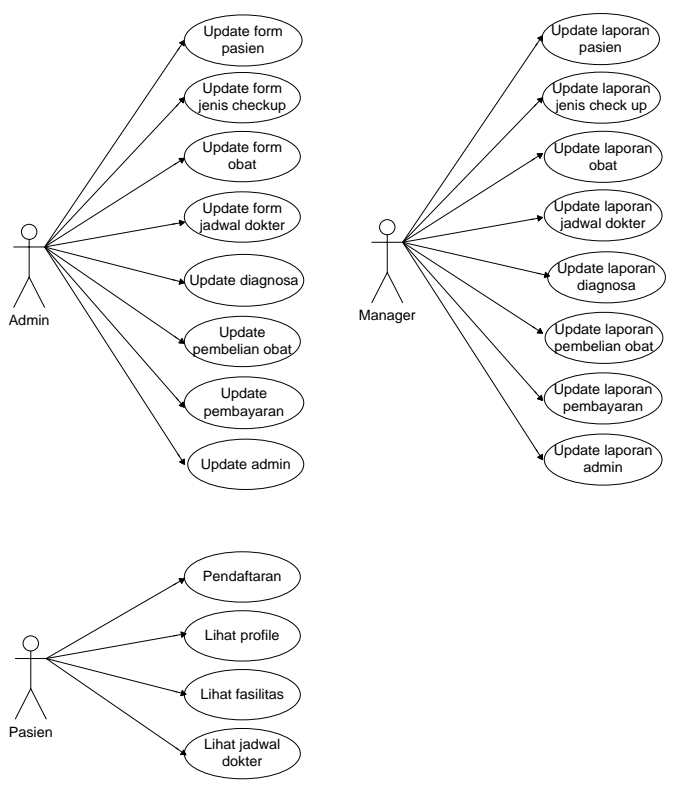

Gambar 1. Business Usecase 


\section{B. Business Object Model}

Merupakan penjelasan lebih lanjut atau rinci dari diagram use-case yang bertujuan untuk mengidentifikasi proses dan interaksi yang terjadi dalam setiap prosesnya. Berikut ini merupakan kegiatan Medical Check Up Rumah Sakit Rawamangun yang digambarkan dalam Business Object Model.

1. Business Object Model Database

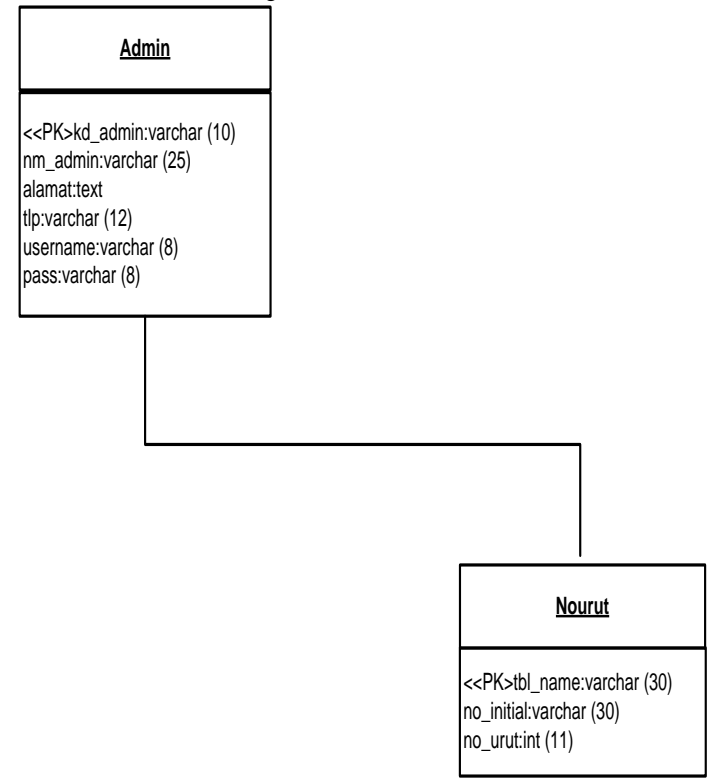

\section{Gambar2. Businness Object Database} Admin

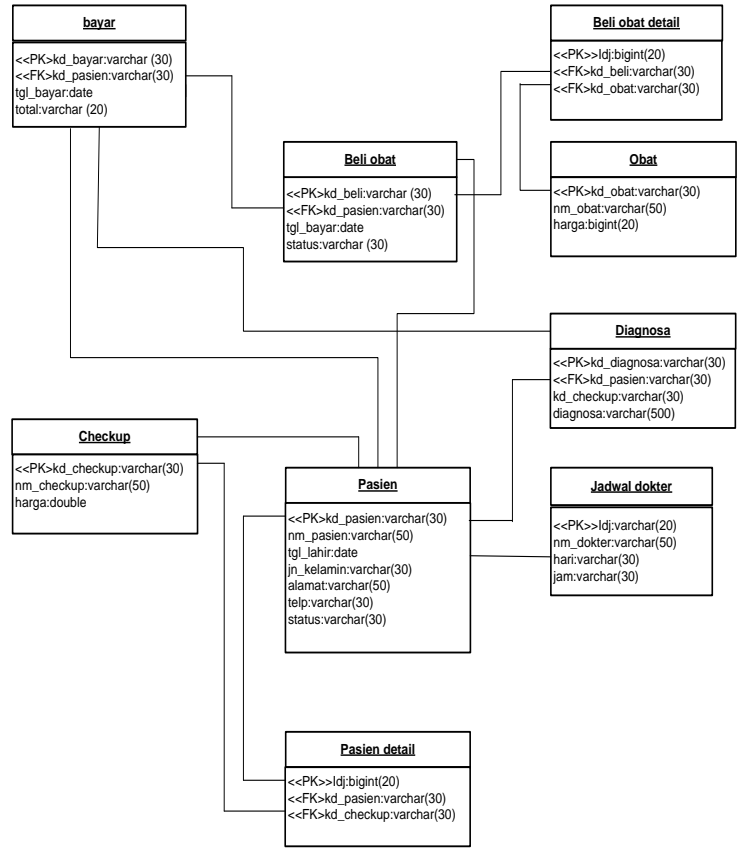

\section{Gambar 3. Businnes Object Model Pasien dan Manager}

\section{Class Diagram}

Class adalah spesifikasi yang jika diinstansiasi akan menghasilkan sebuah objek dan merupakan inti dari pengembangan dan desain berorientasi objek. Class menggambarkan keadaan (atribut/properti) suatu sistem, sekaligus menawarkan layanan untuk memanipulasi keadaan tersebut (metoda/fungsi). Class diagram menggambarkan struktur dan deskripsi class, package dan objek beserta hubungan satu sama lain seperti containment, pewarisan, asosiasi, dan lainlain. 


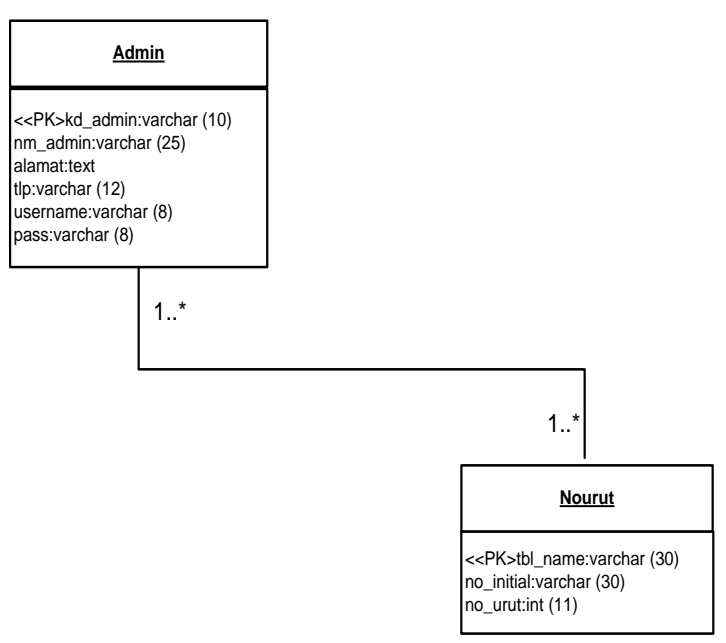

Gambar 4. Class Diagram Admin

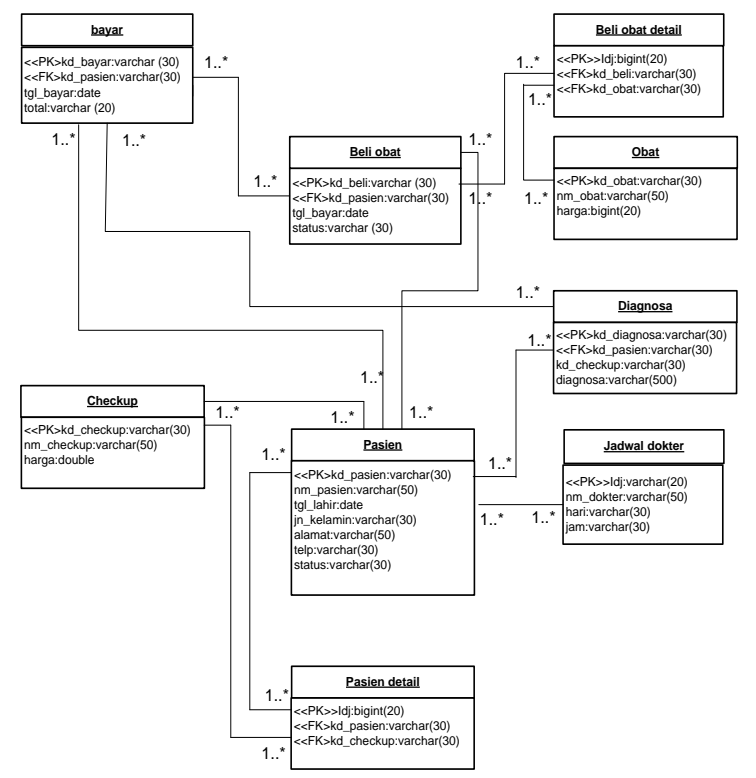

Gambar 5. Class Diagram Admin

\section{Activity Diagram}

Activity Diagram (Hariyanto : 2004) adalah diagram flowchart yang diperluas yang menunjukkan aliran kendali satu aktivitas ke aktivitas lain. Kita dapat menggunakan diagram ini untuk memodelkan aspek dinamis sistem.
1. Activity Diagram Pendaftaran

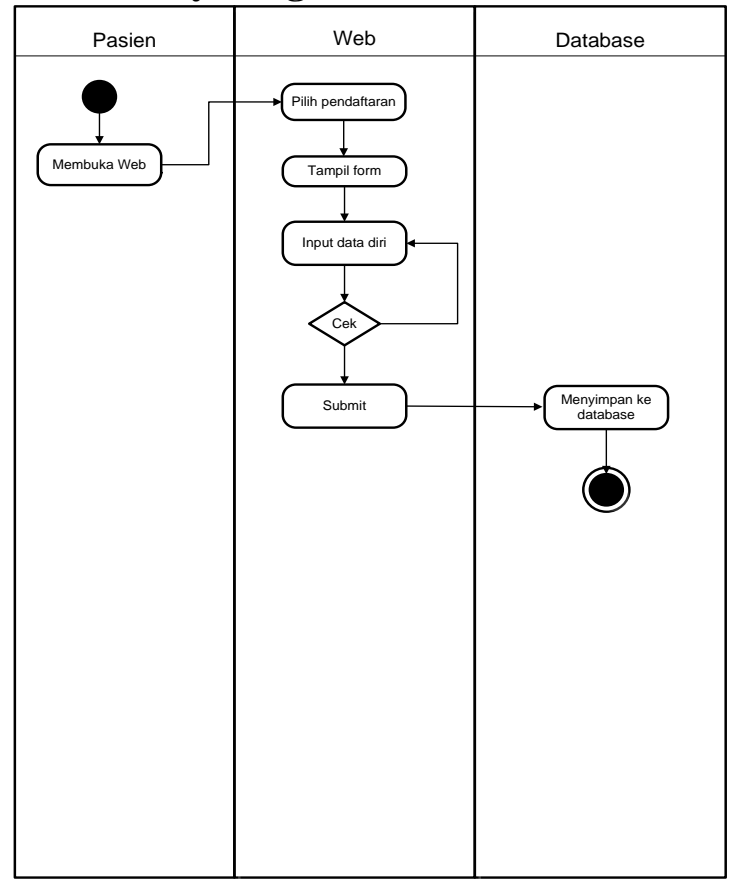

\section{Gambar 6. Activity Diagram Pendaftaran}

\section{Activity Diagram Daftar Pasien}

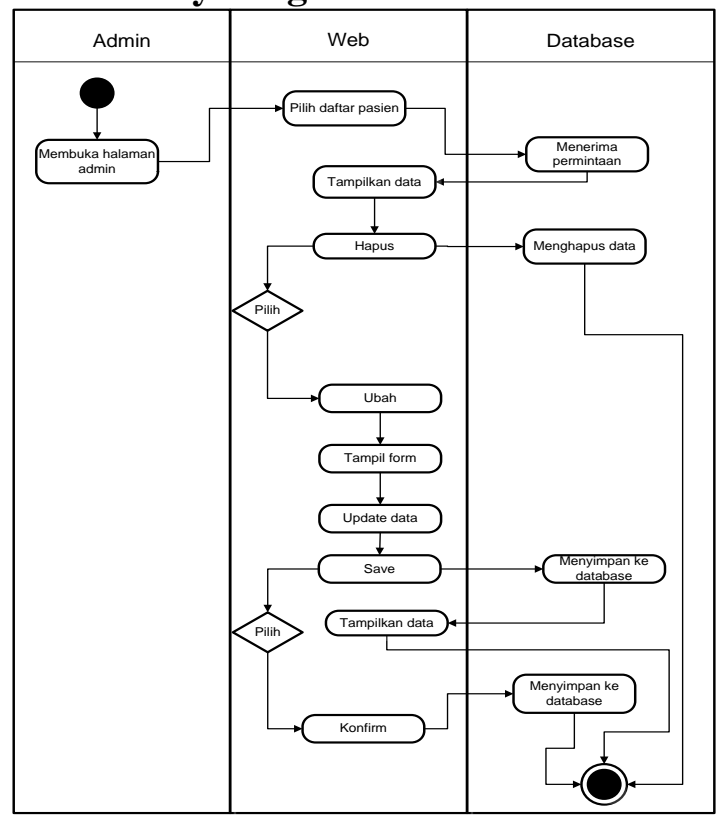

Gambar 7. Activity Diagram Daftar Pasien 
3. Activity Diagram Jenis Check Up

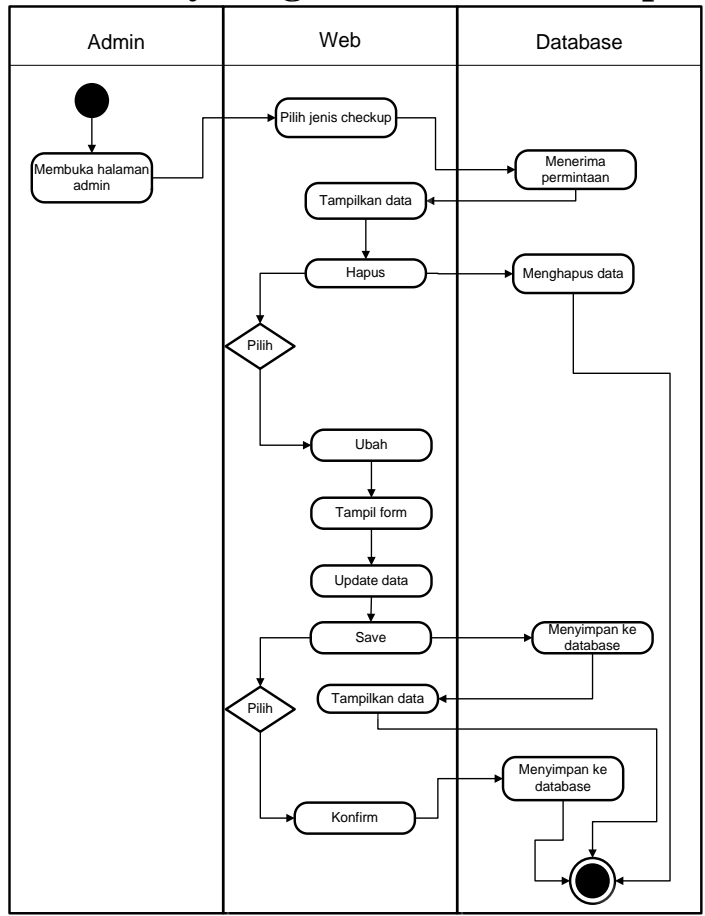

Gambar 8. Activity Diagram Jenis Check Up

4. Activity Diagram Jadwal Dokter

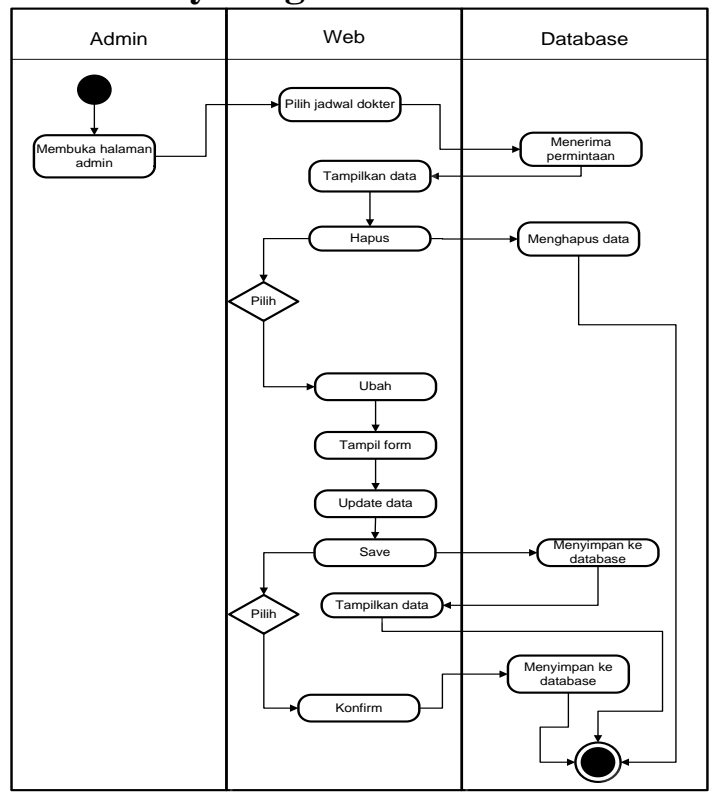

Gambar 9. Activity Diagram Jadwal Dokter
5. Activity Diagram Daftar Obat

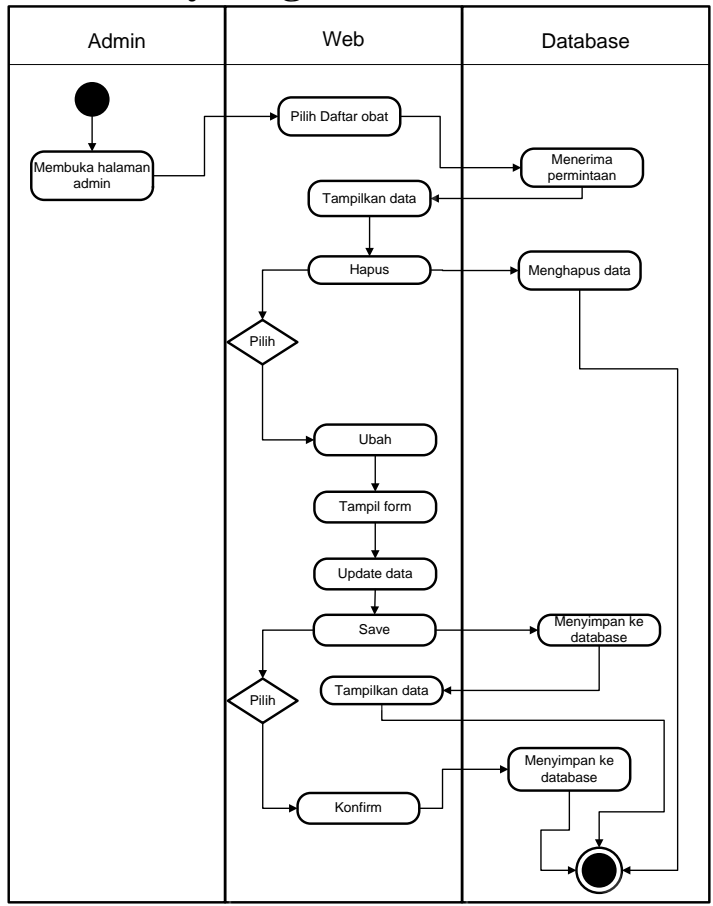

Gambar 10. Activity Diagram Daftar Obat

6. Activity Diagram Diagnosa

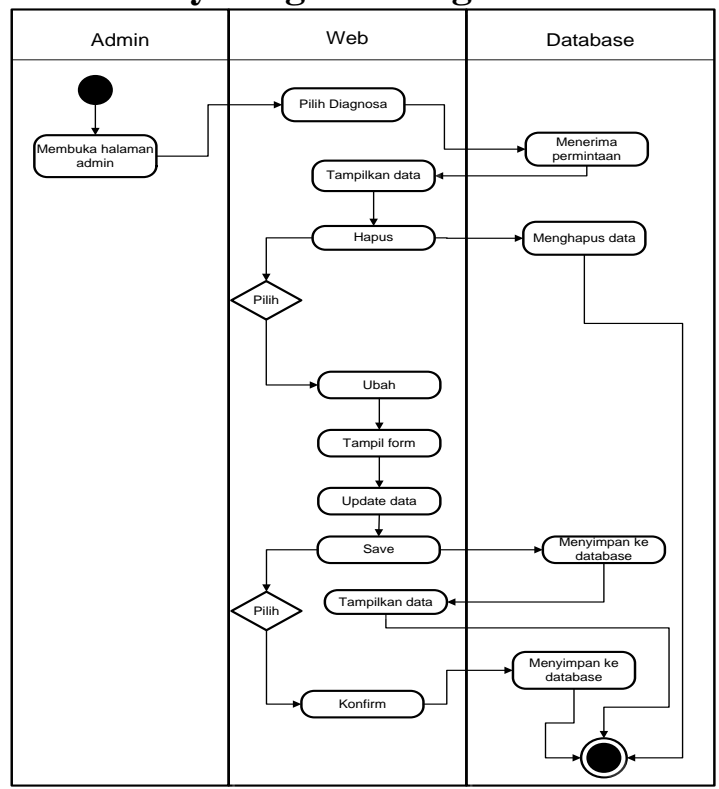

Gambar 11. Activity Diagram Diagnosa 
7. Activity Diagram Pembayaran

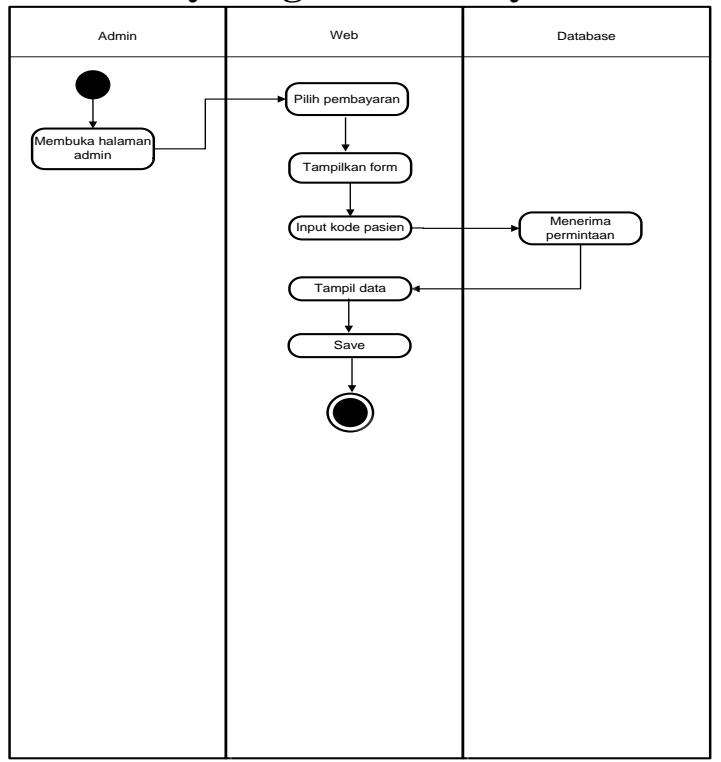

Gambar 12. Activity Diagram Pembayaran

8. Activity Diagram Pembelian Obat

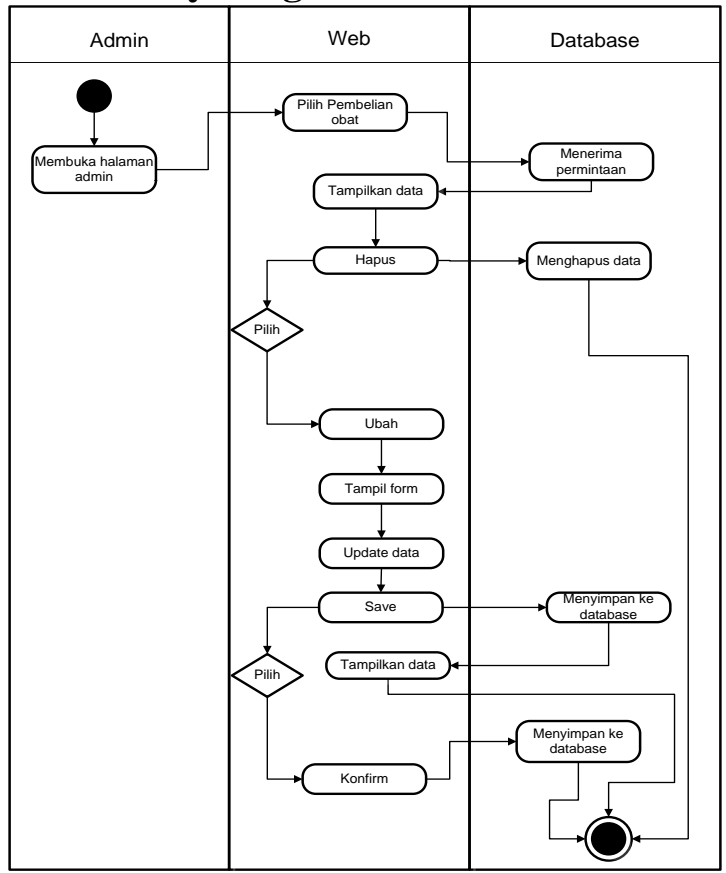

Gambar 13. Activity Diagram Pembelian Obat
9. Activity Diagram Info Admin

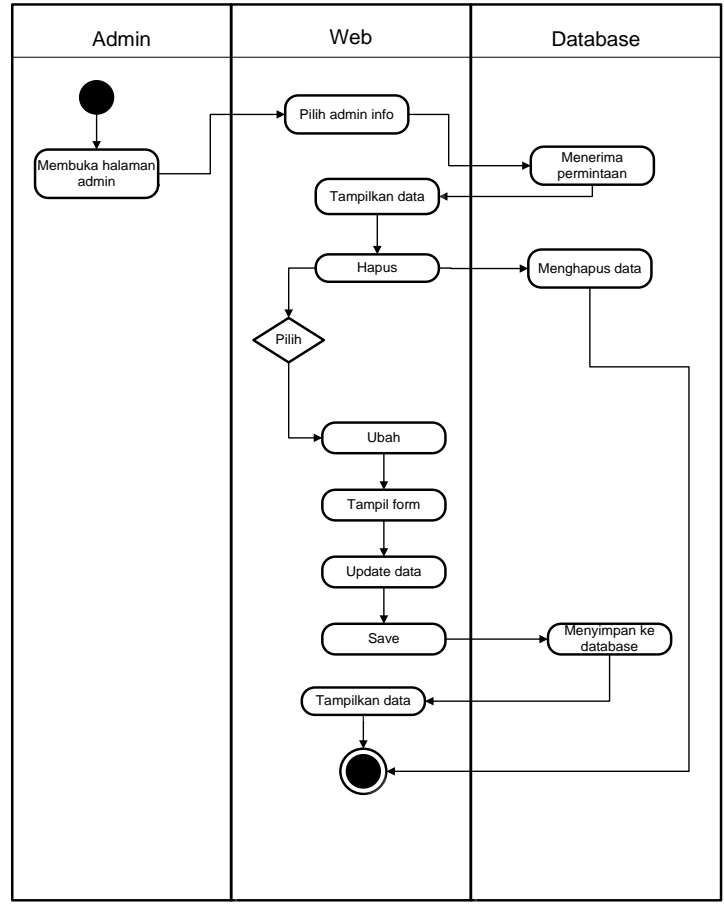

Gambar 14. Activity Diagram Info Admin

10. Activity Diagram Form Pasien

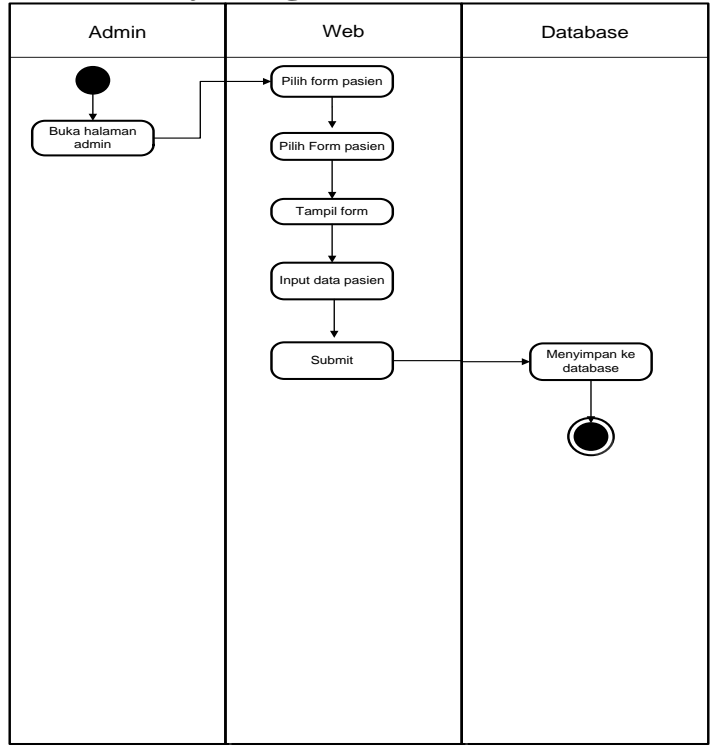

Gambar 15. Activity Diagram Form Pasien 
11. Activity Diagram Form Jenis Check Up

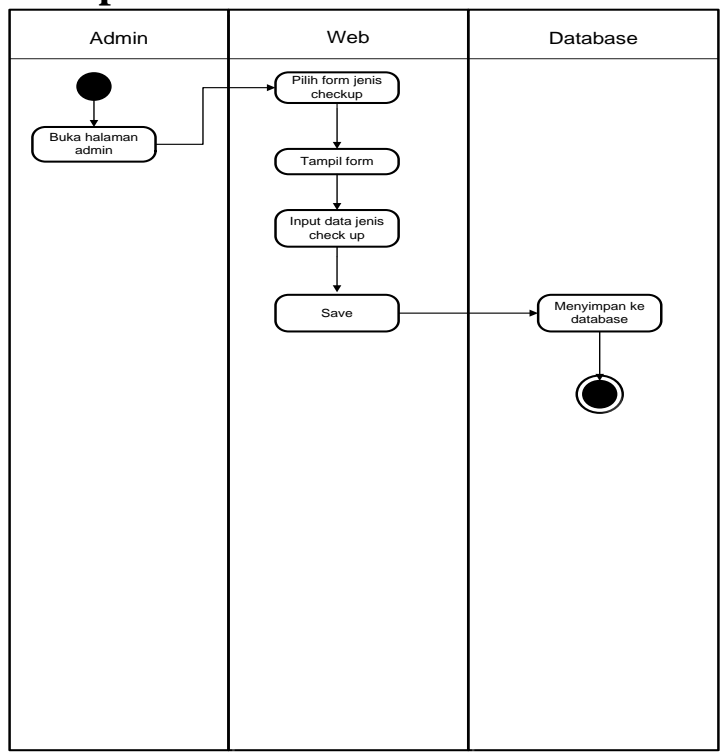

Gambar 16. Activity Diagram Form Jenis Check Up

12. Activity Diagram Form Obat

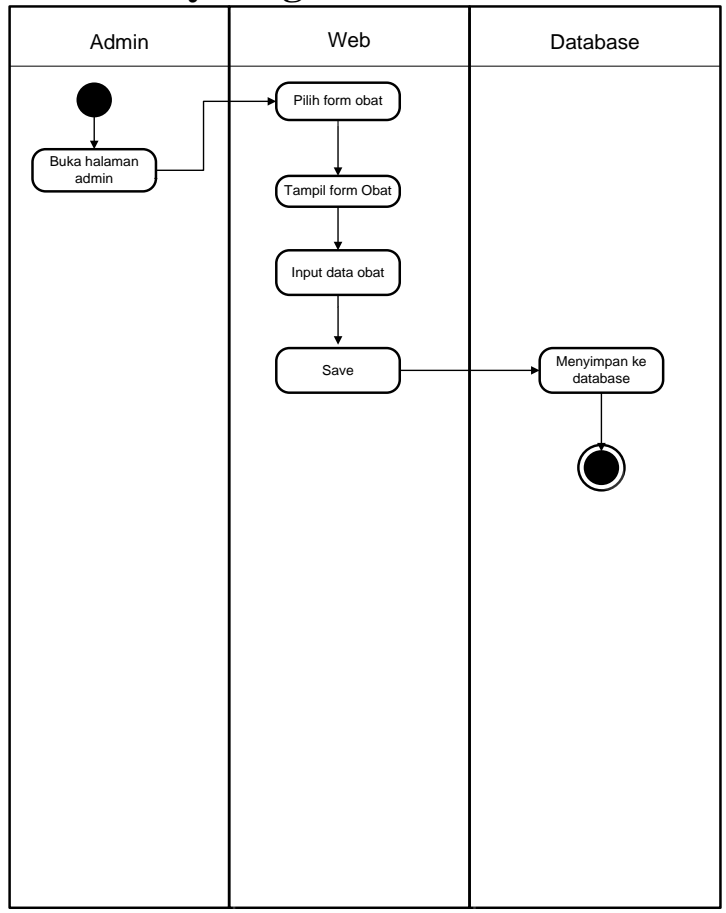

Gambar 17. Activity Diagram Form Obat
13. Activity Diagram Form Jadwal Dokter

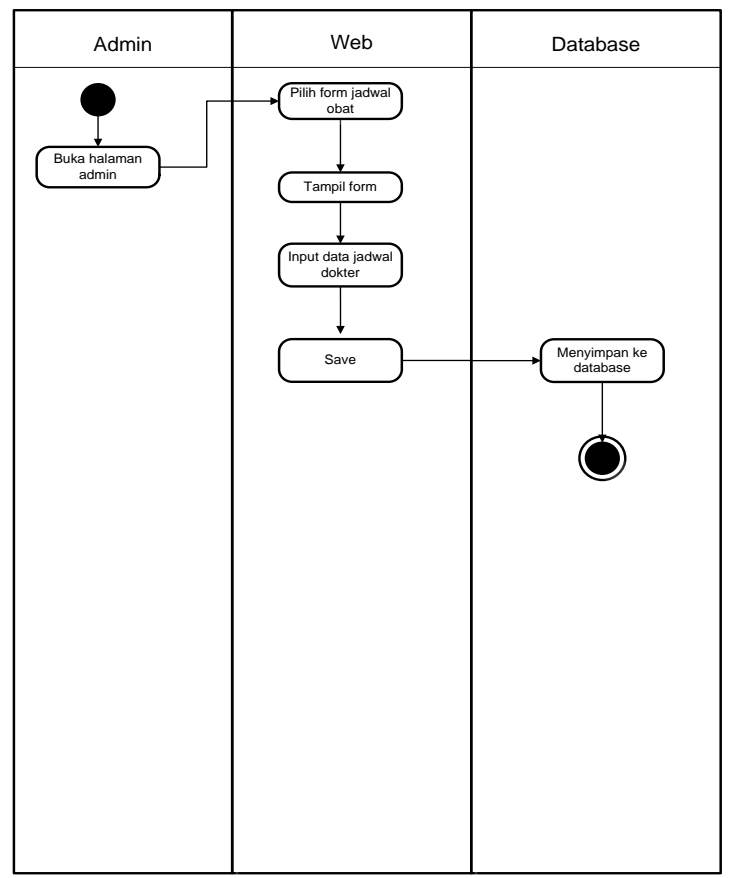

Gambar 18. Activity Diagram Form Jadwal Dokter

14. Activity Diagram Diagnosa

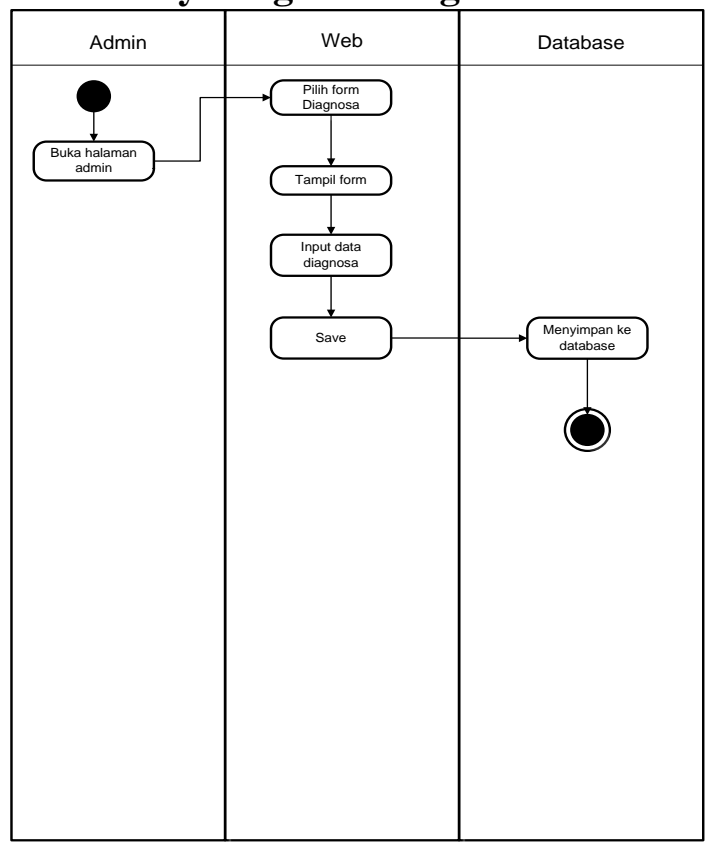

Gambar 19. Activity Diagram Diagnosa 
15. Activity Diagram Pembelian Obat

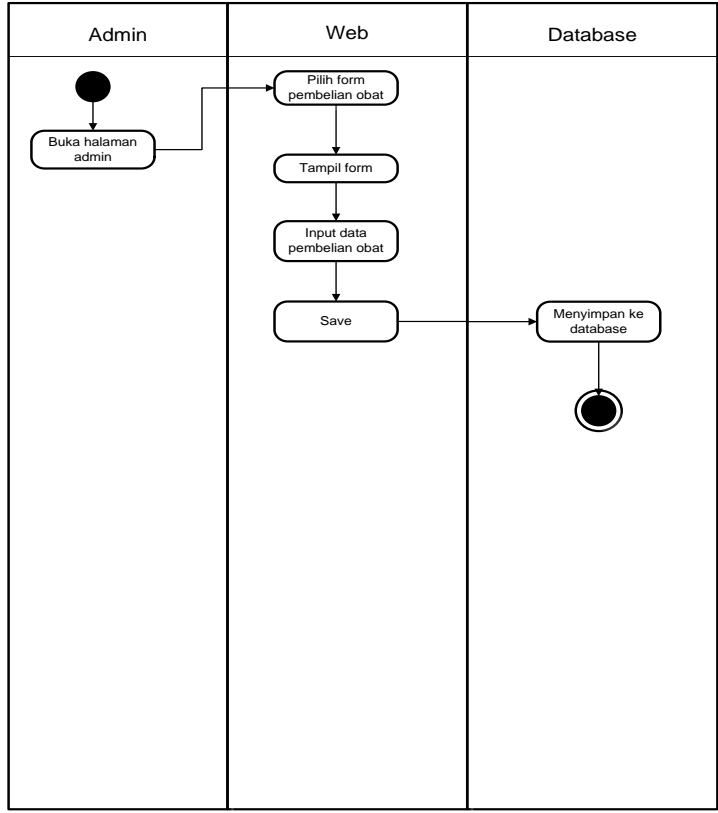

Gambar 20. Activity Diagram Pembelian Obat

\section{Activity Diagram Pembayaran}

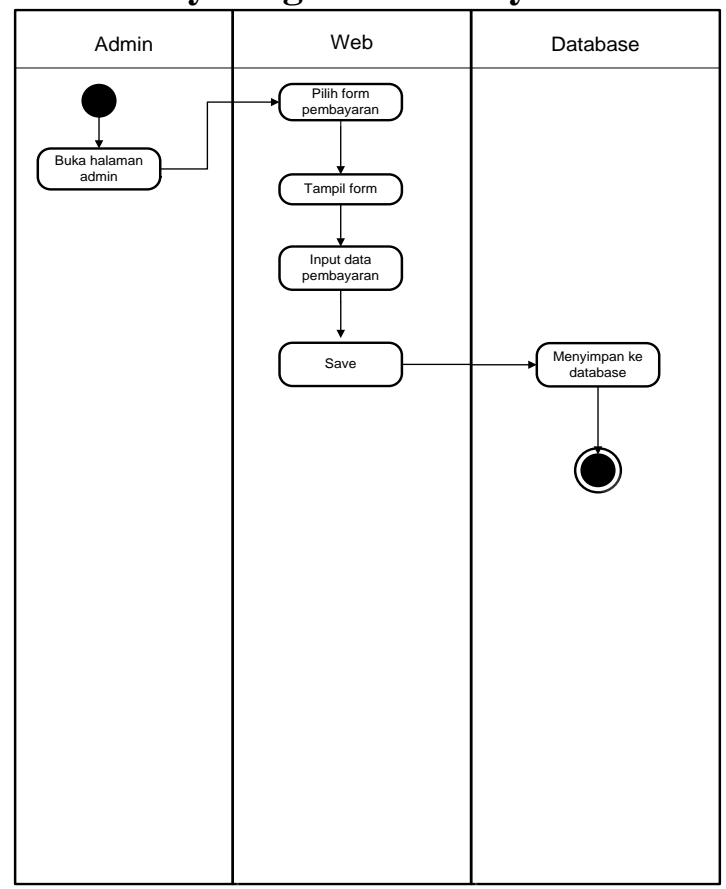

Gambar 21. Activity Diagram Pembayaran

\section{Activity Diagram Form Admin}

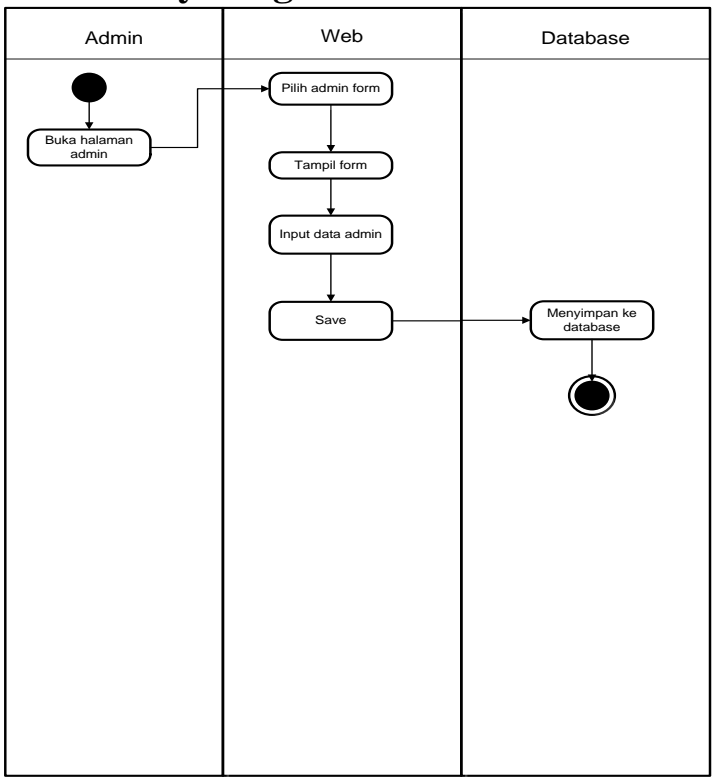

Gambar 22. Activity Diagram Form Admin

\section{Sequence Diagram}

Sequence Diagram menggambarkan perilaku pada sebuah skenario, diagram ini menunjukkan sejumlah contoh objek dan message (pesan) yang diletakkan diantara objek-objek didalam use case. Masingmasing objek, termasuk aktor, memiliki lifeline vertikal. Message digambarkan sebagai garis berpanah dari satu objek ke objek lainnya. Pada fase desain berikutnya, message akan dipetakan menjadi operasi/metode dari class. Activation bar menunjukkan lamanya eksekusi sebuah proses, biasanya diawali dengan diterimanya sebuah message. 
1. Sequence Diagram Login Admin

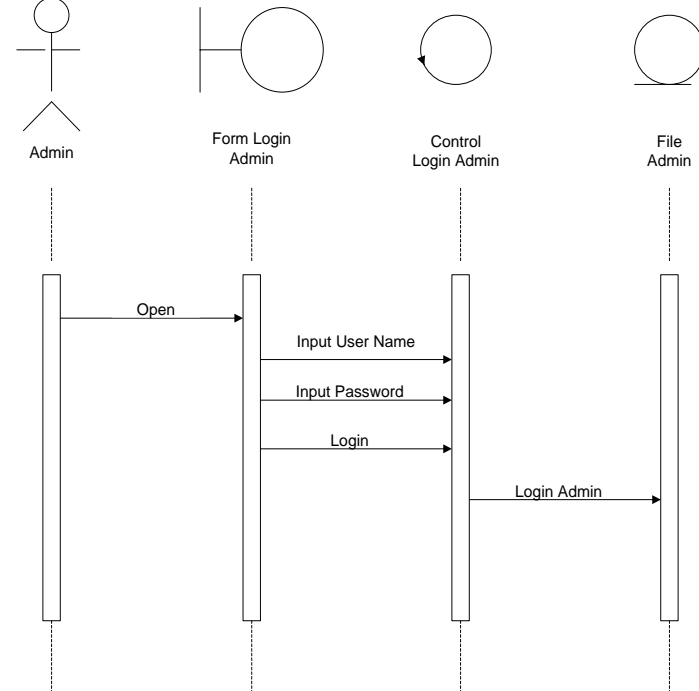

Gambar 23. Sequence Diagram Login Admin

\section{Sequence Diagram Daftar Pasien}

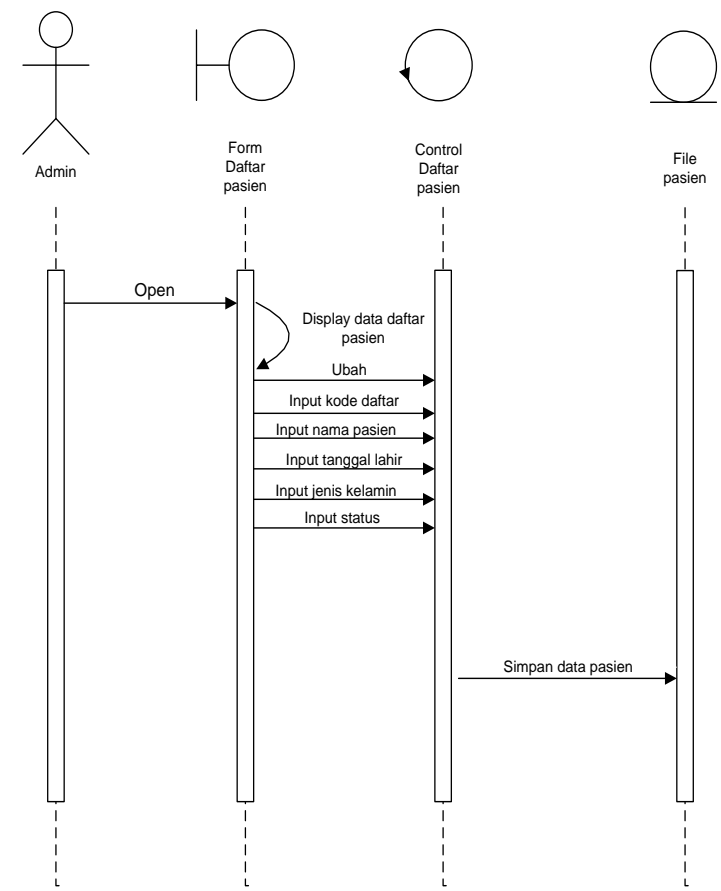

Gambar 24. Sequence Diagram Daftar Pasien
3. Sequence Diagram Update Admin

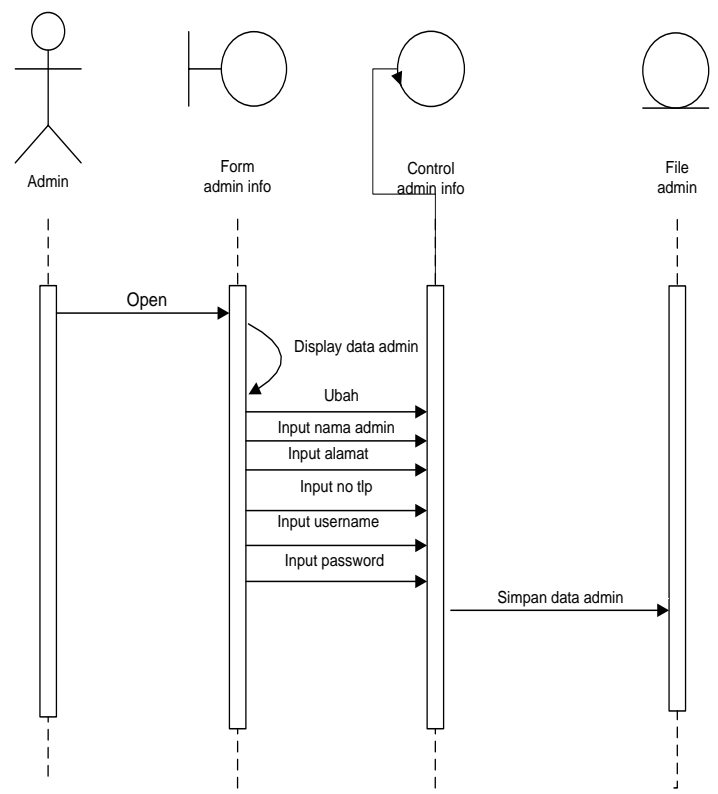

Gambar 25. Sequence Diagram Update Admin

4. Sequence Diagram Pendaftaran

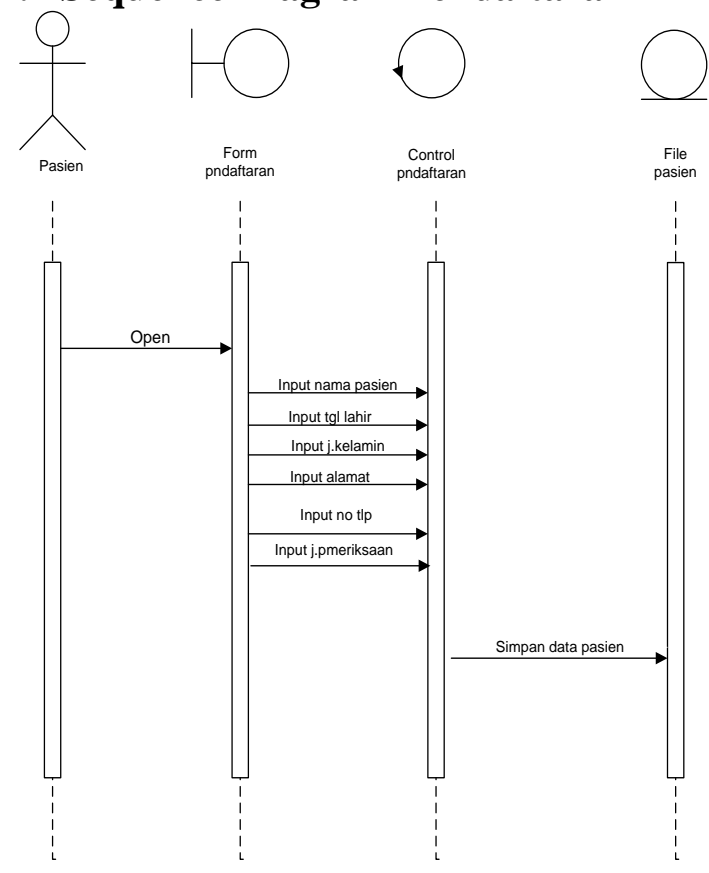

Gambar 26. Sequence Diagram Pendaftaran 
5. Sequence Diagram Jenis Check Up<smiles>OC1CC1</smiles>
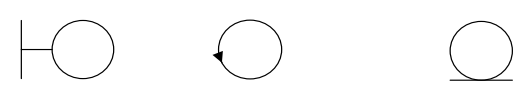

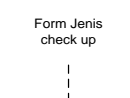

Control
Jenis
checkup<smiles>C1CC2CCC1C2</smiles><smiles>C1COOC1</smiles>
$\rightarrow$ \begin{tabular}{|c|} 
Ubah \\
\hline Input kode checkup \\
\hline
\end{tabular} $\underset{\text { Harga }}{\stackrel{\longrightarrow}{\longrightarrow}}$ ( (1) (1)

$$
\begin{gathered}
1 \\
1 \\
1 \\
1 \\
1
\end{gathered}
$$

Gambar 27. Sequence Diagram Jenis Check Up

6. Sequence Diagram Jadwal Dokter

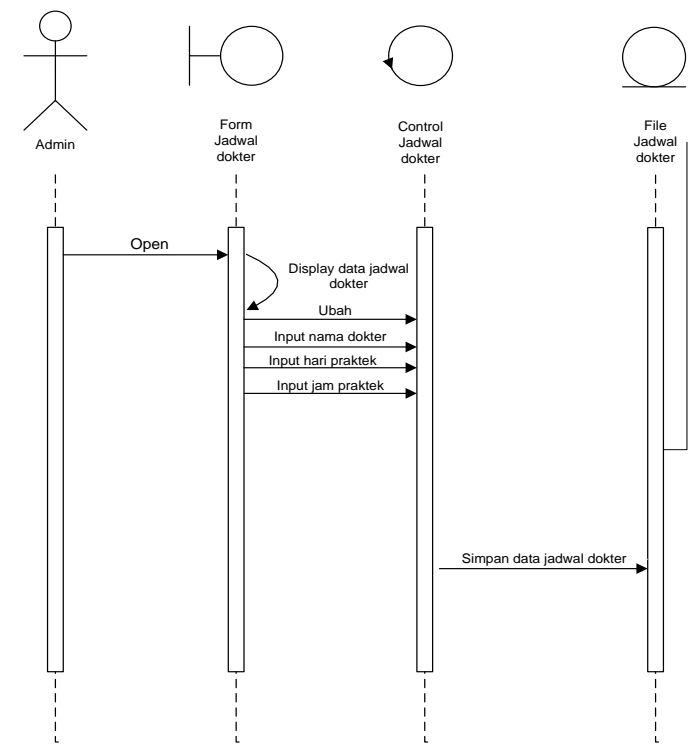

Gambar 28. Sequence Diagram Jadwal Dokter
7. Sequence Diagram Daftar Obat

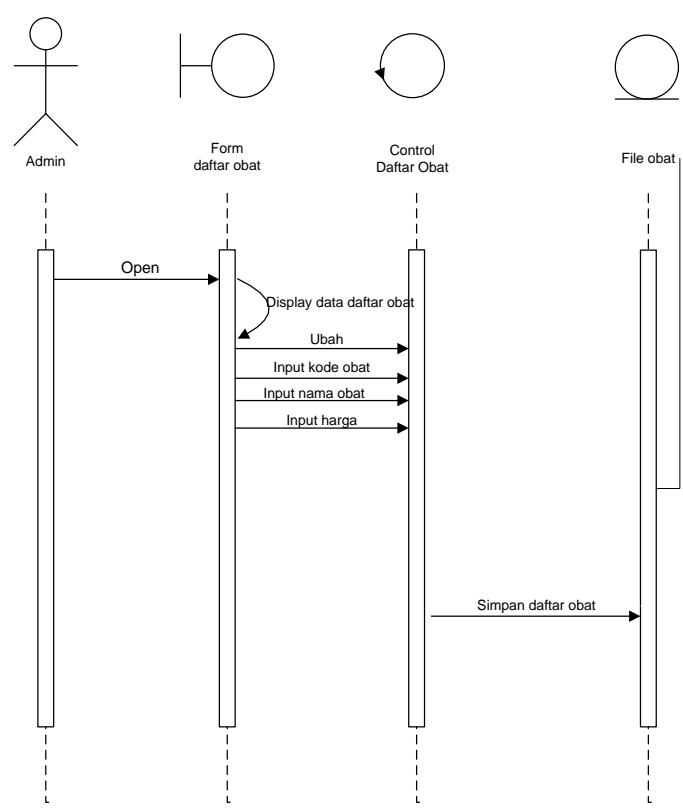

Gambar 29. Sequence Diagram Daftar Obat

8. Sequence Diagram Diagnosa

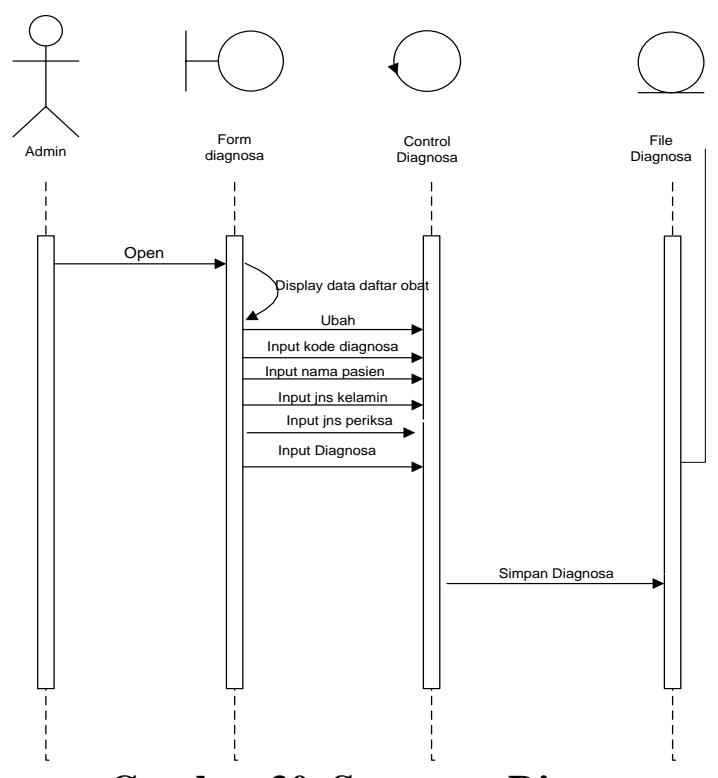

Gambar 30. Sequence Diagram Diagnosa 
9. Sequence Diagram Pembayaran

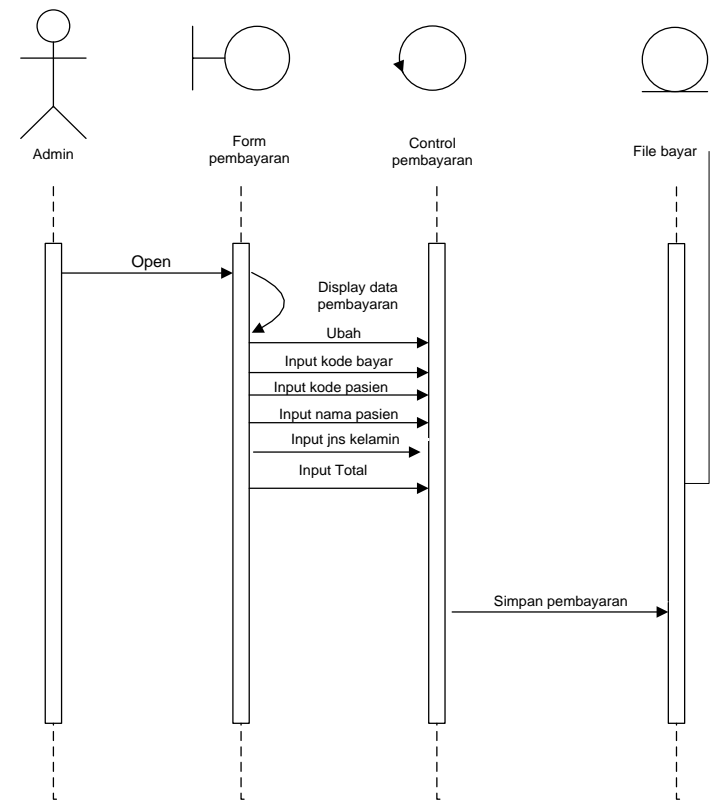

Gambar 31. Sequence Diagram Pembayaran

10. Sequence Diagram Pembelian Obat

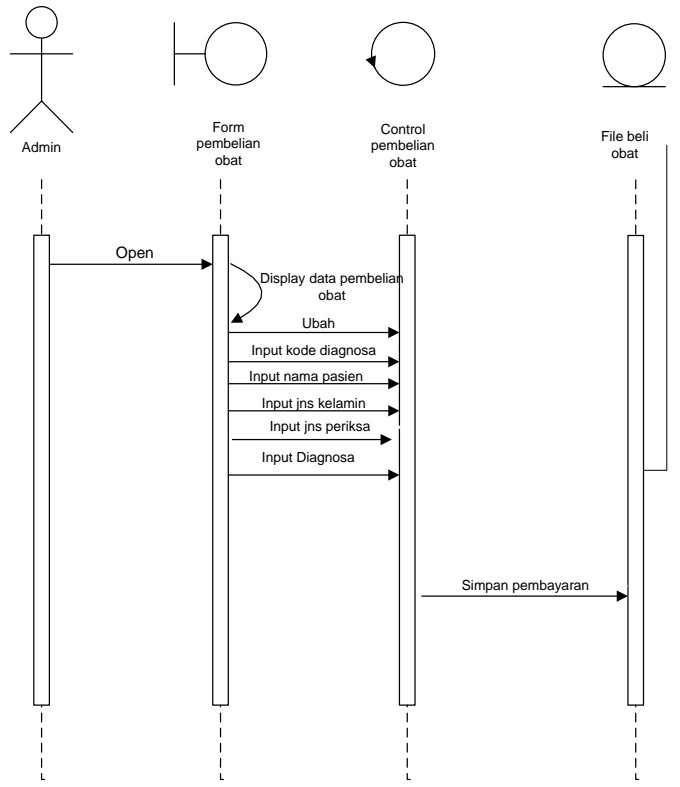

Gambar 32. Sequence Diagram Pembelian Obat
11. Sequence Diagram Admin info

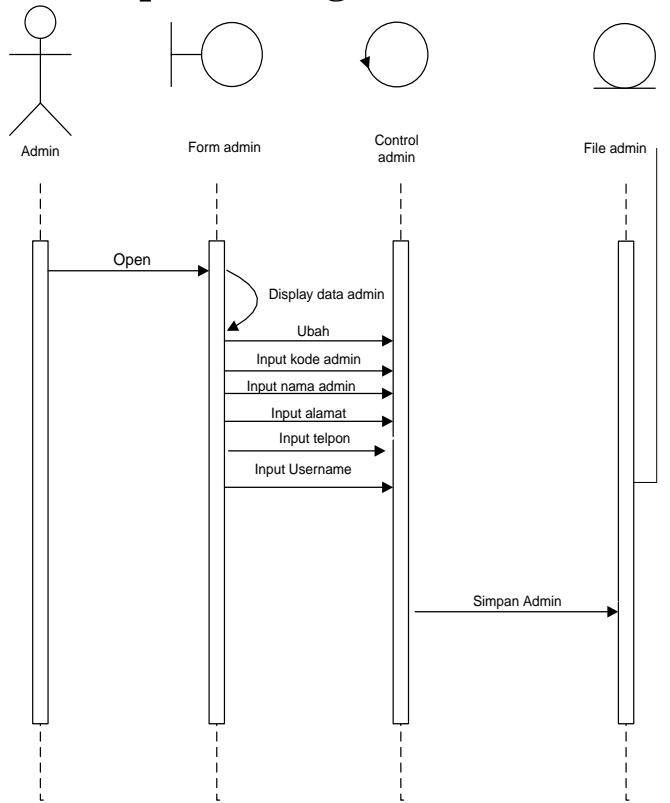

Gambar 33. Sequence Diagram Admin

12. Sequence Diagram Delete Pembayaran

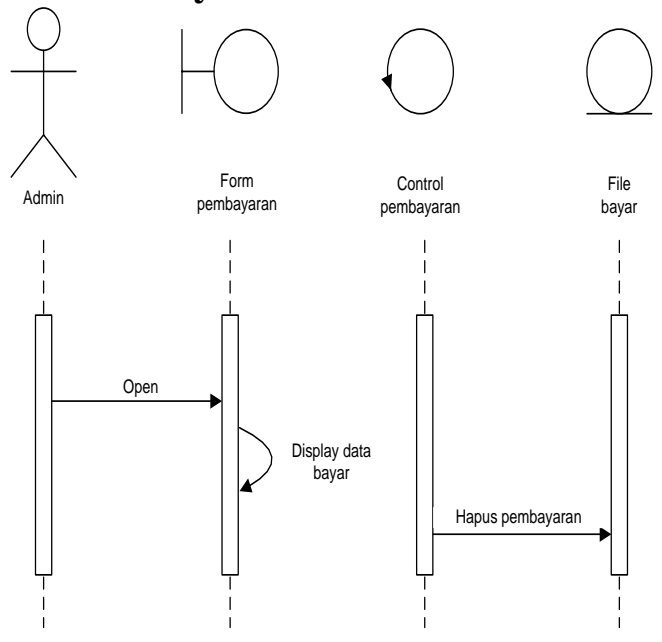

Gambar 34. Sequence Diagram delete Pembayaran 
13. Sequence Diagram Delete Admin

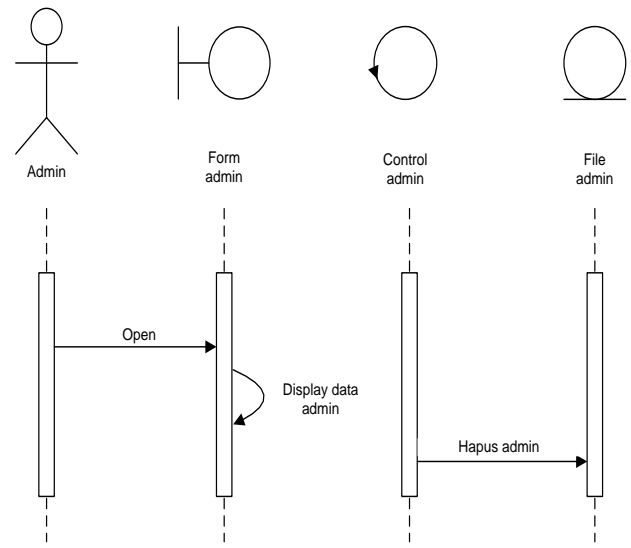

Gambar 35. Sequence Diagram delete Admin

\section{Sequence Diagram Input}

Pembayaran

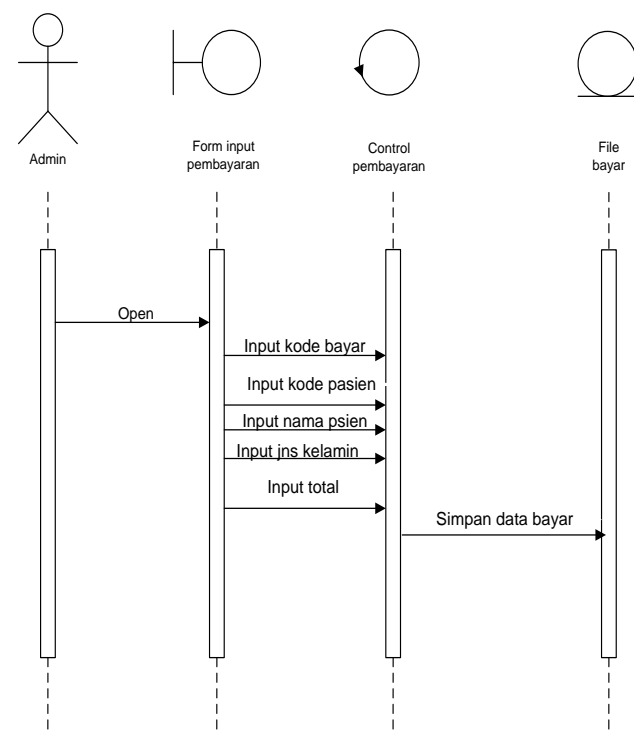

Gambar 36. Sequence Diagram Input Pembayaran
15. Sequence Diagram input Admin

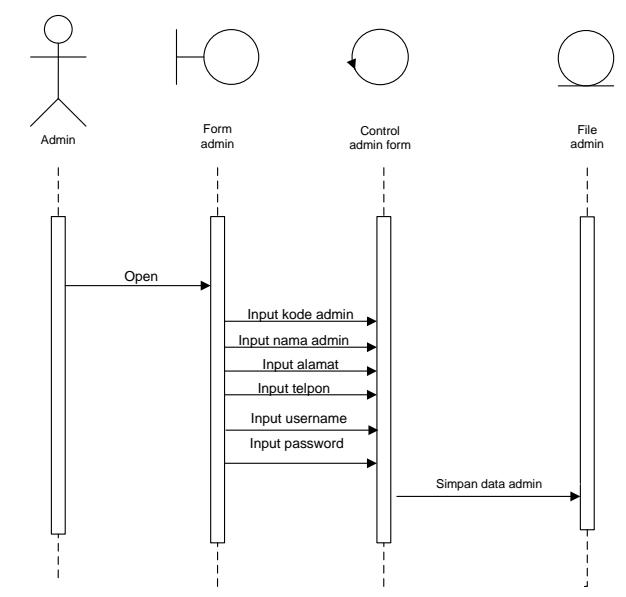

Gambar 37. Sequence Diagram input admin

\section{Sequence Diagram Update}

Pembayaran

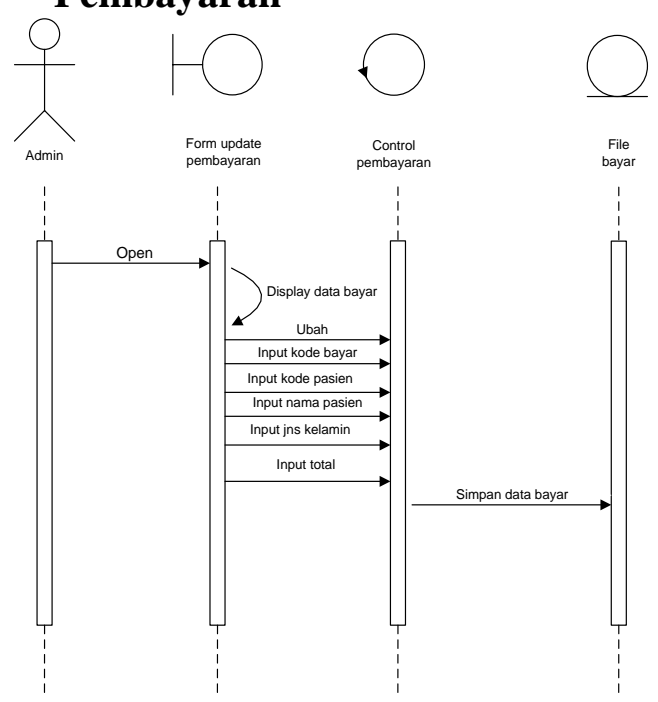

Gambar 38. Sequence Diagram

Update Pembayaran 


\section{Sequence Diagram Konfirm Pasien}

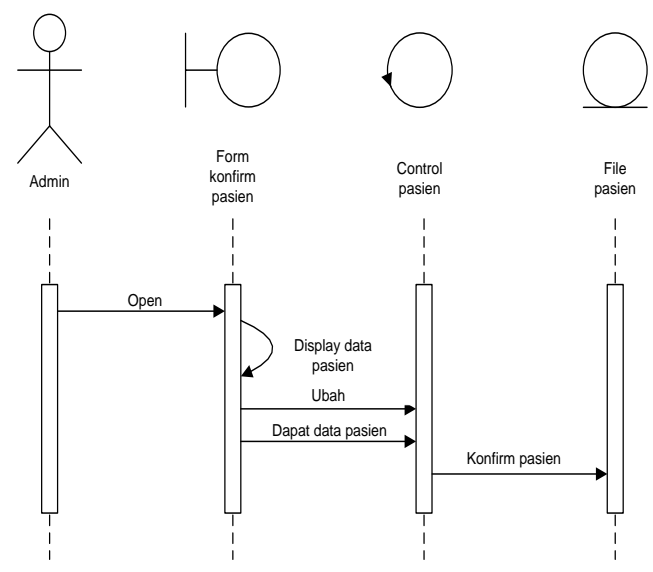

Gambar 39. Sequence Diagram Konfirm Pasien

\section{PEMBAHASAN}

\section{Analisis Pendaftaran Pasien Rawat Jalan Rumah Sakit Rawamangun}

\section{A. Prosedur Kasus}

Dalam melakukan pendaftaran pasien rawat jalan rumah sakit ada saja masalah yang akan dihadapi, diantaranya pasien terkadang tidak mendapatkan informasi yang akurat dan tepat, sesuai yang dibutuhkan oleh pasien yang ingin melakukan pendaftaran pasien rawat jalan. Dikarenakan pencatatan data-data pasien yang tidak terupdate setiap saat, front office yang tidak selalu berada di tempatnya. Atau juga kesalahan dalam mencatat data pasien dan tanggal pasien untuk melakukan pendaftaran pasien rawat jalan. Sehingga pasien yang ingin melakukan rawat jalan akan mengalami kesulitan, belum lagi dengan adanya kesalahan informasi dari pasien ke front office atau sebaliknya.
Permasalahan yang sering dihadapi dalam melakukan pendaftaran pasien rawat jalan antara lain :

2. Informasi rumah sakit yang tidak dapat diketahui jika tidak datang langsung ke rumah sakit

3. Informasi data-data pasien yang tidak terupdate setiap saat.

4. Pasien sulit untuk melakukan rawat jalan dikarenakan pendaftaran hanya dapat datang langsung ke rumah sakit, tidak dapat mendaftar dimana seorang pasien terhubung dengan internet.

5. Kesalahan dalam input data pasien, dan untuk melakukan update membutuhkan waktu yang lama.

Berdasarkan penelitian sebagai alternatif pemecahan masalah diatas, maka penulis mengajukan solusi untuk mengurangi permasalahan diatas dimana cara pembelajarannya dirubah karena sekarang adalah dunia teknologi dan disegala bidang sudah menggunakan komputer maka para pasien juga harus mengikutinya dengan belajar menggunakan internet, yaitu sebagai berikut:

1. Untuk mempermudah dalam pendaftaran pasien, mengetahui fasilitas dan jadwal dokter yang disediakan oleh rumah sakit dengan melihatnya melalui internet. Pasien akan mendapatkan bukti pembayaran rawat jalan jika sudah membayar.

2. Untuk penyampaian informasi tidak harus datang langsung ke rumah sakit. Dan tidak takut kesalahan penyampaian informasi pasien ke rumah sakit karena dilakukan langsung oleh pasien itu sendiri 
melalui website pendaftaran rumah sakit.

\section{B. Membuat Tampilan Website \\ 1. Halaman Index.php}

Halaman ini berfungsi sebagai halaman depan / homepage. didalam halaman ini terdiri dari menu pilihan yang dapat di lihat oleh user.

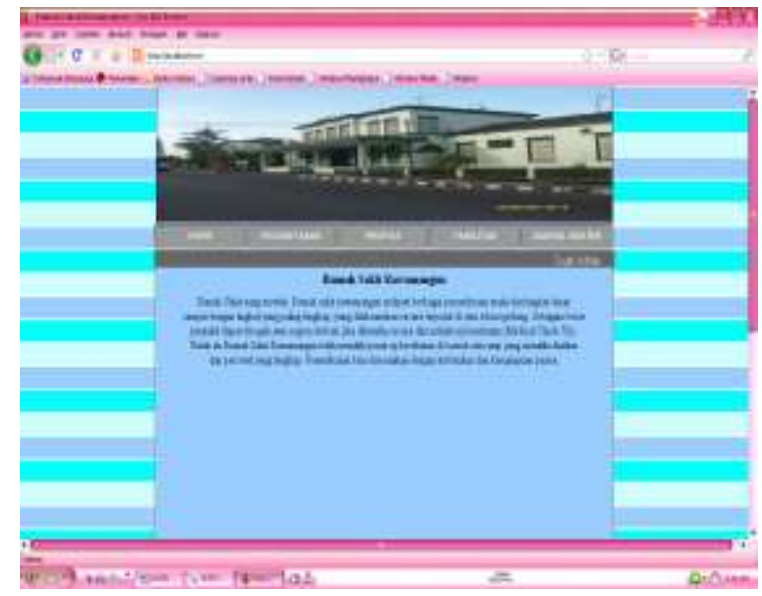

\section{Gambar 40. Halaman Index.php}

\section{Profile}

Halaman ini menampilkan informasi tentang profile rawat jalan serta misi dan visi untuk pengembangan rumah sakit

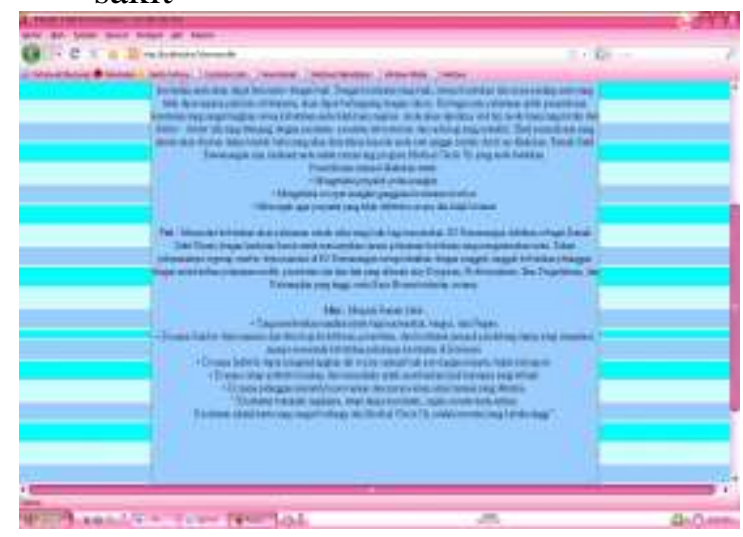

Gambar 41. Profile

\section{Fasilitas}

Halaman ini menampilkan informasi tentang fasilitas yang terdapat di rumah sakit dan dapat dimanfaatkan oleh pasien yang ingin melakukan rawat jalan.

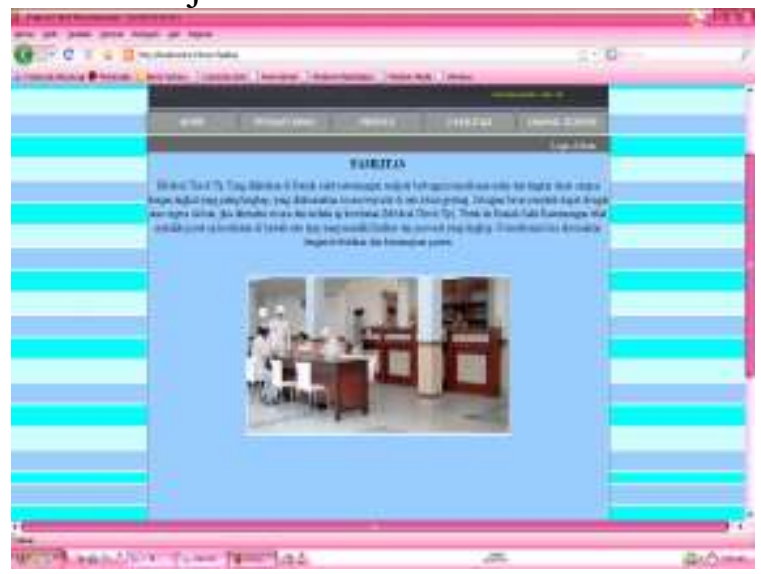

Gambar 42. Fasilitas

\section{Jadwal Dokter}

Halaman ini menampilkan informasi tentang jadwal dokter yang praktek dalam rumah sakit.

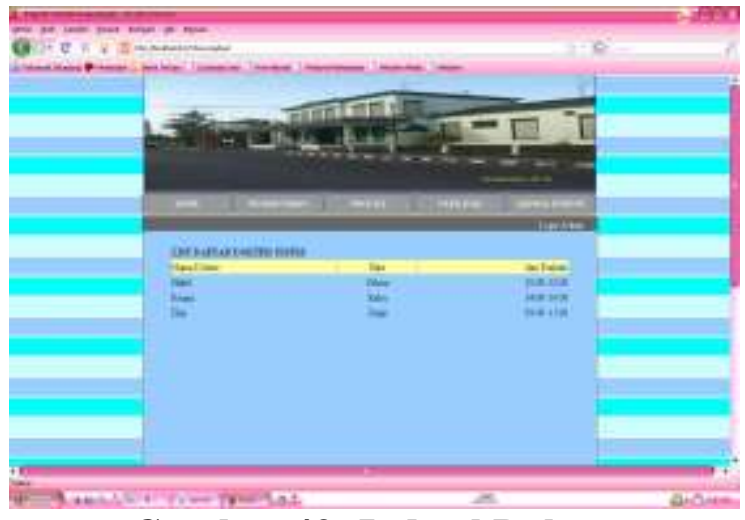

Gambar 43. Jadwal Dokter

\section{Pendaftaran}

Halaman ini menampilkan form pendaftaran untuk pasien yang ingin melakukan rawat jalan secara online langsung ke dalam database rumah sakit rawamangun. 


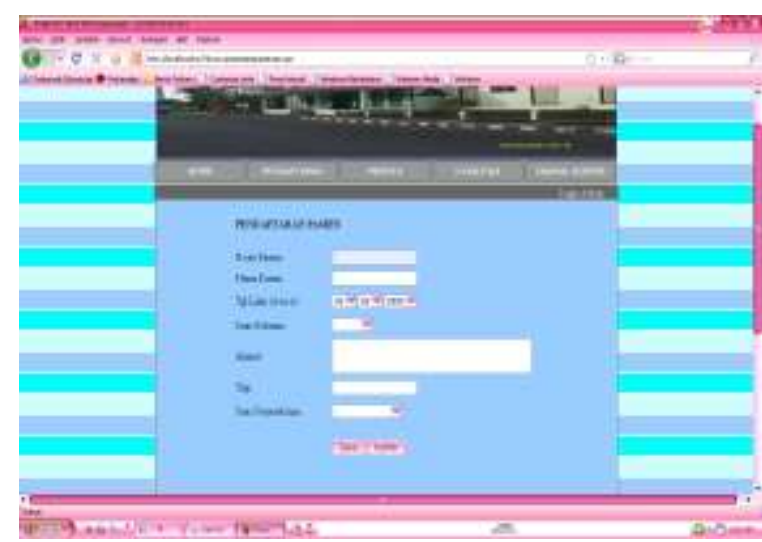

Gambar 44. Pendaftaran

\section{Halaman admin}

Halaman admin ini menampilkan pengaturan dan penambahan data-data yang dibutuhkan. Seperti data daftar pasien, jenis check up, jadwal dokter, daftar obat, diagnosa, pembayaran, pembelian obat, dan info admin.

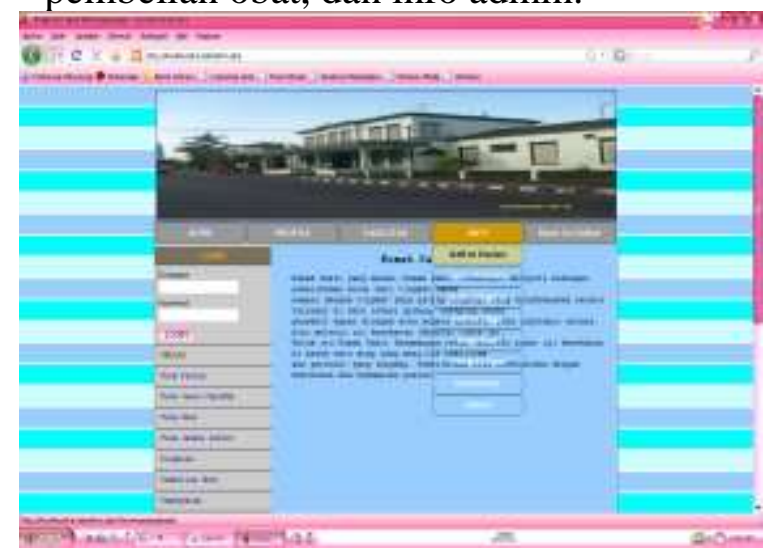

\section{Gambar 45. Halaman admin}

\section{Form Rawat Jalan}

Halaman ini menampilkan form rawat jalan dan langsung terupdate di halaman online pada menu rawat jalan pada info.

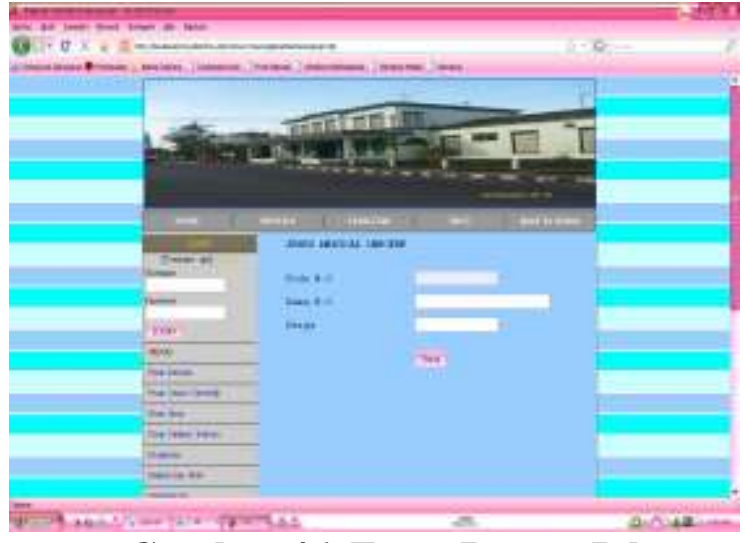

Gambar 46. Form Rawat Jalan

\section{Form Obat}

Halaman ini menampilkan form obat dan langsung terupdate di halaman online pada menu daftar obat pada info.

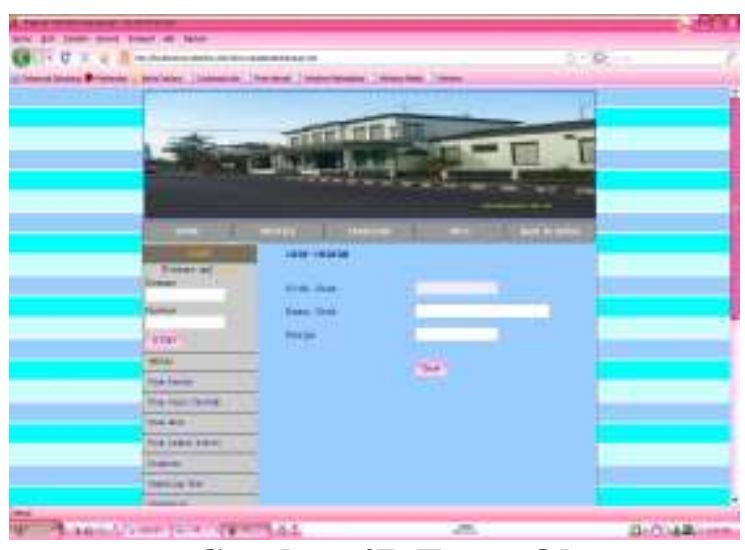

\section{Gambar 47. Form Obat}

\section{Form Jadwal Dokter}

Halaman ini menampilkan form jadwal dokter dan langsung terupdate di halaman online pada menu jadwal dokter pada info. 


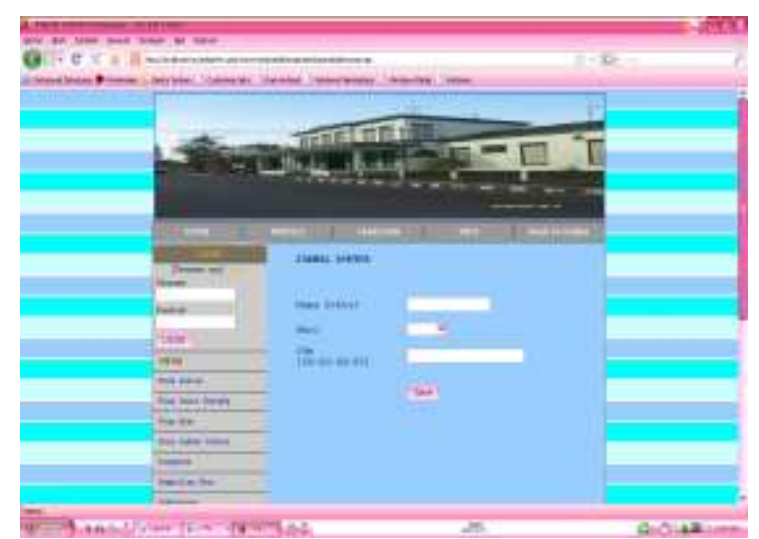

Gambar 48. Form Jadwal dokter

10. Diagnosa

Halaman ini menampilkan form diagnose dan langsung terupdate di halaman online pada menu diagnose pada info.

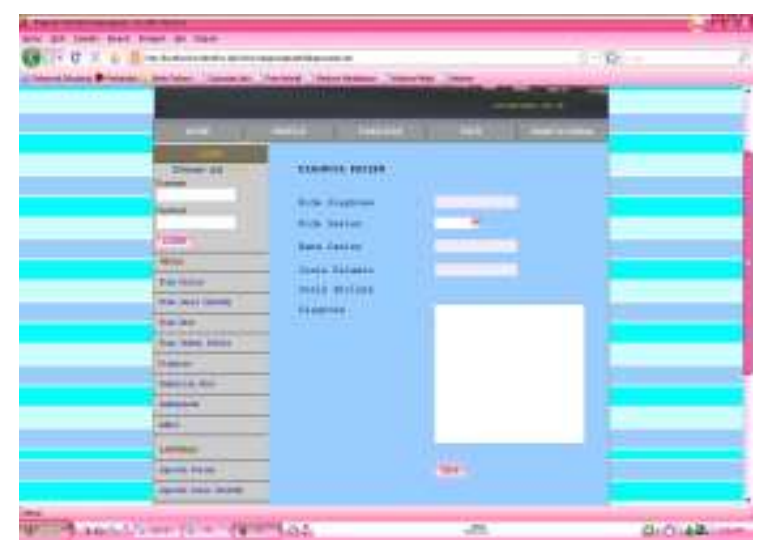

\section{Gambar 49. Diagnosa}

\section{Pembelian Obat}

Halaman ini menampilkan form pembelian obat dan langsung terupdate di halaman online pada menu pembelian pada info.

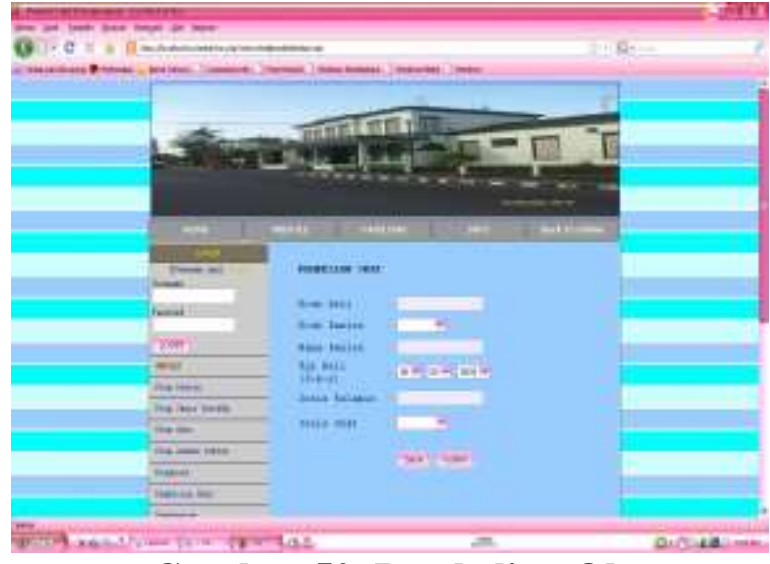

Gambar 50. Pembelian Obat

\section{Pembayaran}

Halaman ini menampilkan form pembayaran dan langsung terupdate di halaman online pada menu pembayaran pada info.

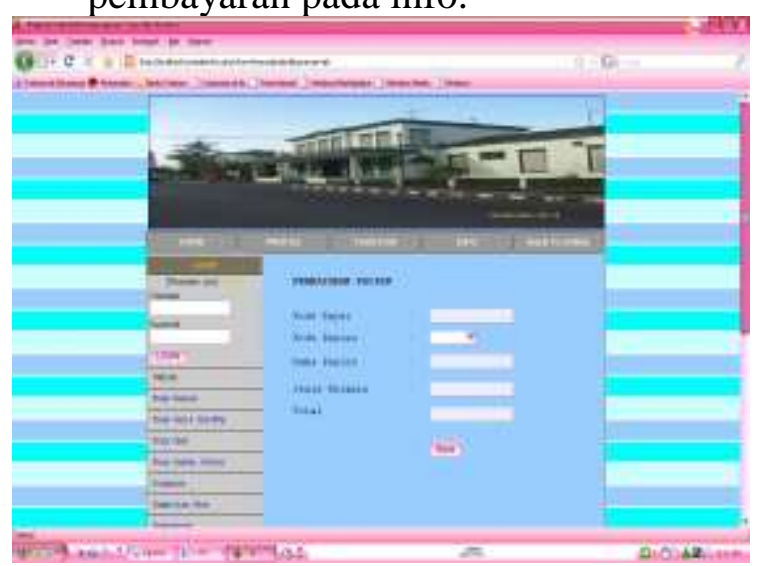

\section{Gambar 51. Pembayaran}

\section{Admin}

Halaman ini menampilkan form input admin baru jika ada sewaktu-waktu penambahan tenaga kerja pada bagian admin. 


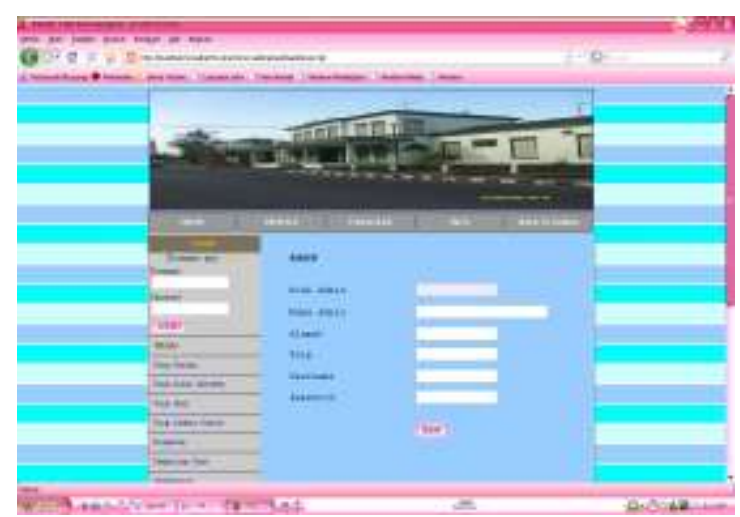

Gambar 52. Admin

\section{Daftar Pasien}

Halaman ini menampilkan data pasien yang telah melakukan rawat jalan tertulis detail untuk arsip rumah sakit rawamangun, dan data pasien bisa diupdate sekaligus pasien dapat melakukan konfirmasi ulang jika benar ia melakukan rawat jalan.

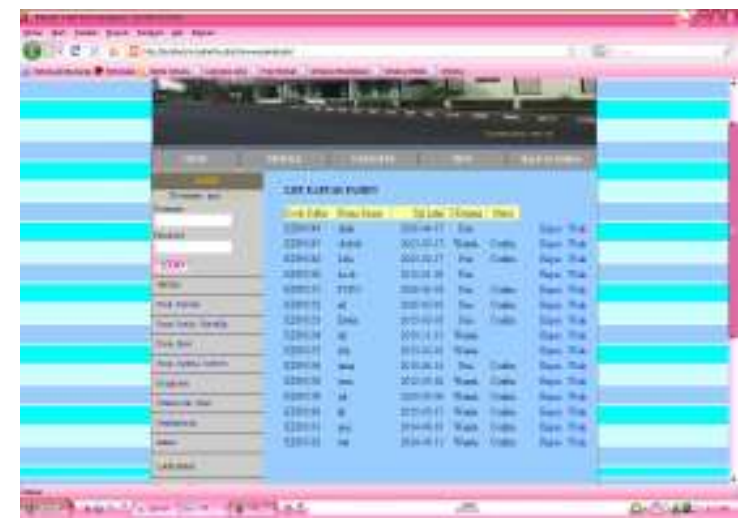

Gambar 53. Daftar Pasien

\section{Jenis Rawat Jalan}

Halaman ini menampilkan informasi tentang jenis rawat jalan yang tersedia beserta harganya.

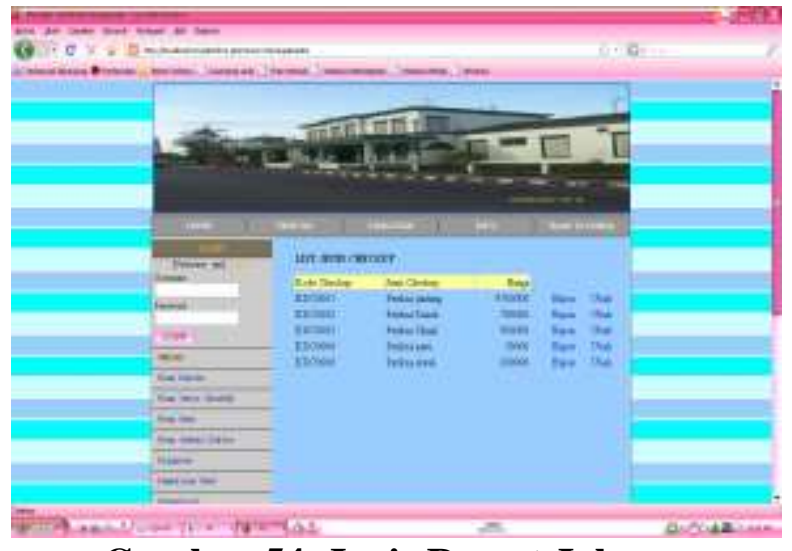

Gambar 54. Jenis Rawat Jalan

16. Jadwal Dokter

Halaman ini menampilkan informasi tentang nama dokter yang praktek beserta hari dan jamnya.

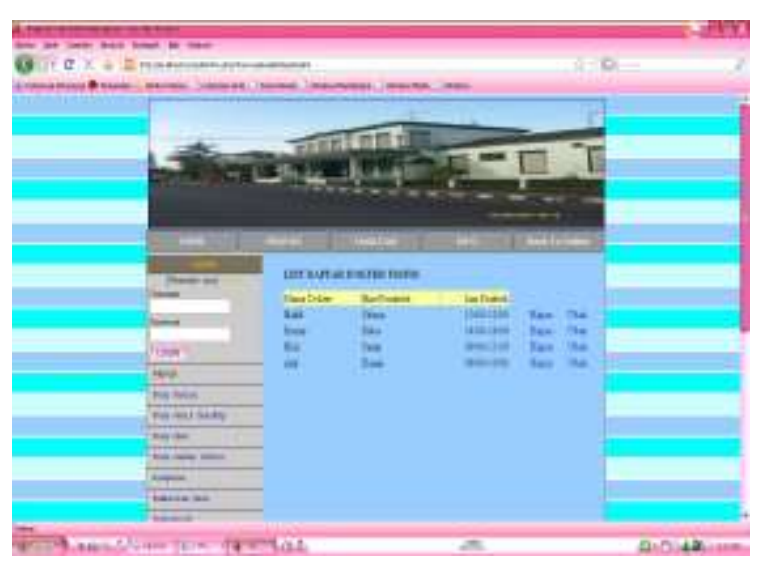

Gambar 55. Jadwal Dokter

\section{Daftar Obat}

Halaman ini menampilkan informasi tentang nama obat yang dibutuhkan beserta harganya. 


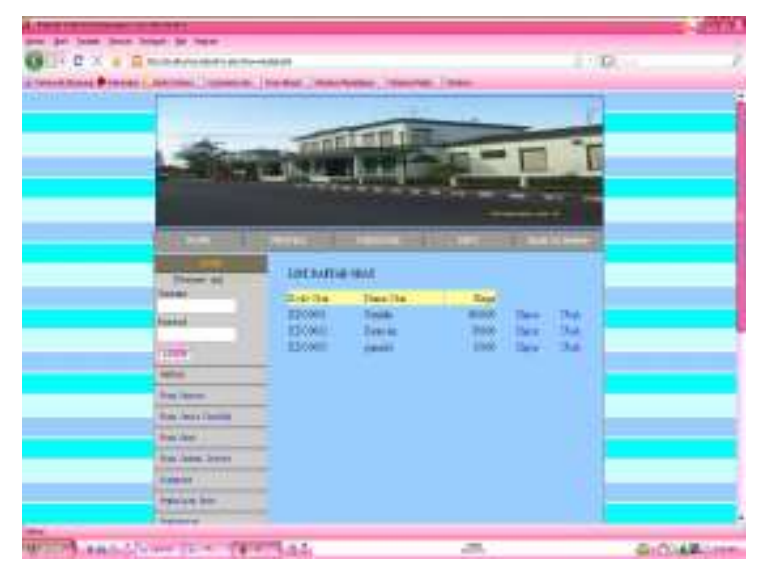

Gambar 56. Daftar Obat

18. Diagnosa

Halaman ini menampilkan informasi tentang penyakit pasien yang telah di diagnose oleh dokter.

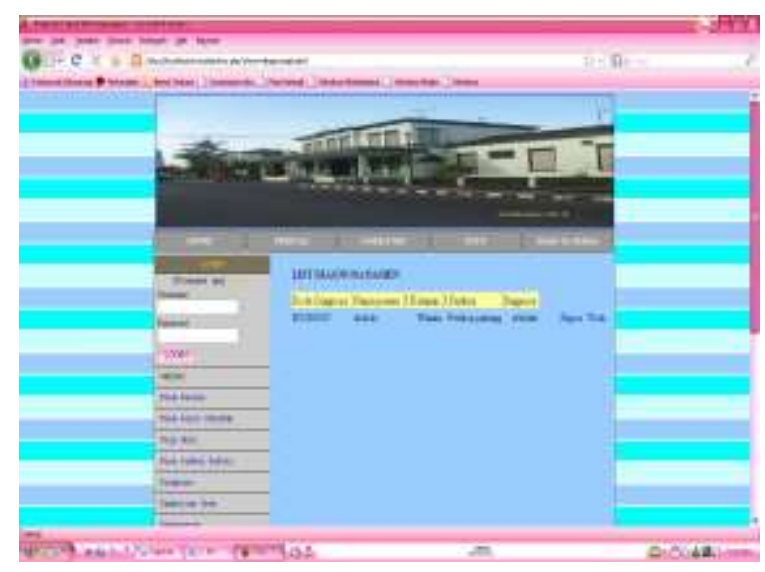

\section{Gambar 57. Diagnosa}

\section{Pembayaran}

Halaman ini menampilkan data pasien yang sudah membayar biaya rawat inap dan memerlukan laporan ulang untuk keterangan pasien tersebut.

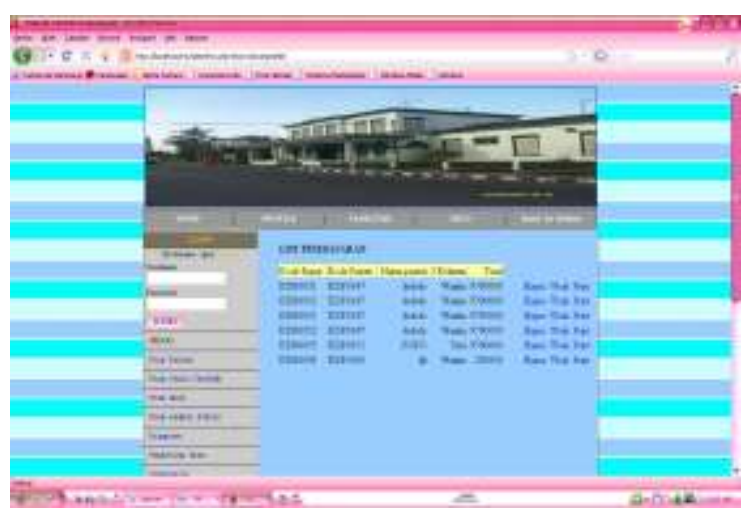

\section{Gambar 58. Pembayaran}

\section{Pembelian}

Halaman ini menampilkan data yang berisi tentang informasi pasien yang membeli obat.

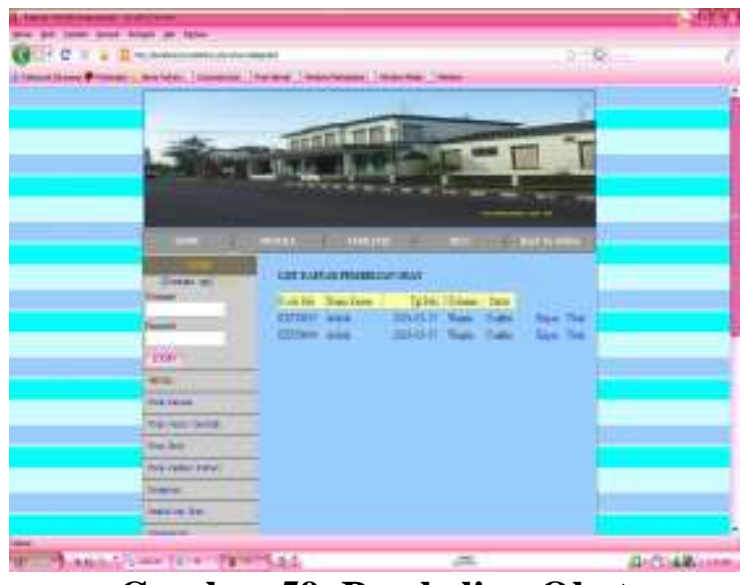

\section{Gambar 59. Pembelian Obat}

\section{Admin}

Halaman ini menampilkan data-data admin yang masih aktif atau masih digunakan. 


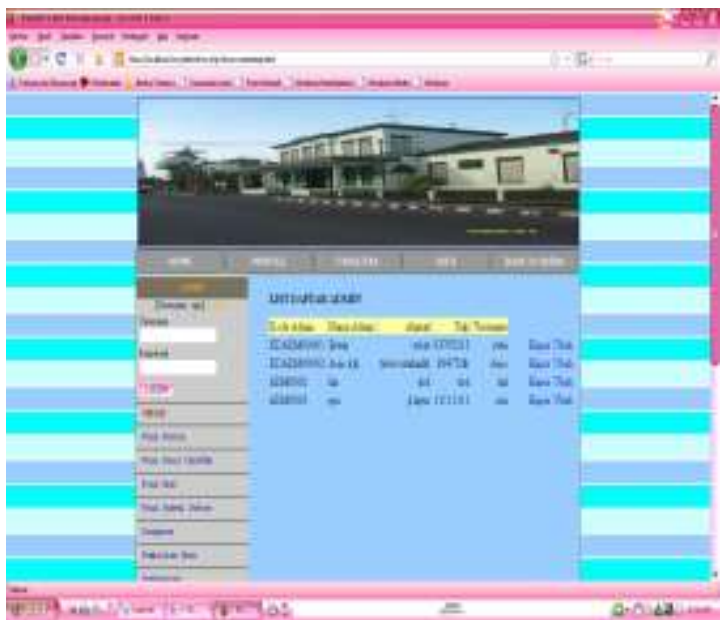

Gambar 60. Admin info

22. Laporan Pasien

Halaman ini menampilkan laporan pasien yang melakukan medical check up untuk manager rumah sakit rawamangun.
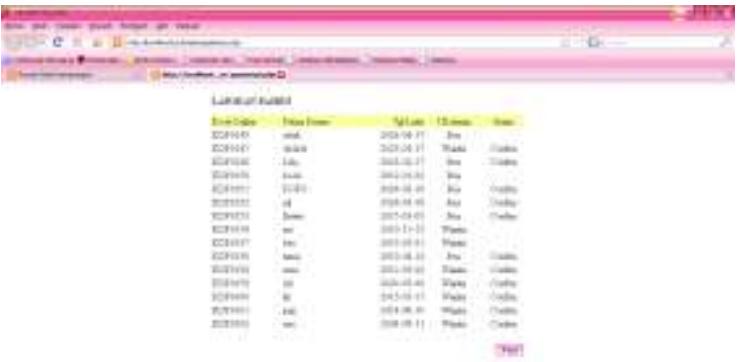

\section{Gambar 61. Laporan Pasien}

23. Laporan Jenis Rawat Jalan

Halaman ini menampilkan laporan jenis rawat inap untuk manager rumah sakit rawamangun.

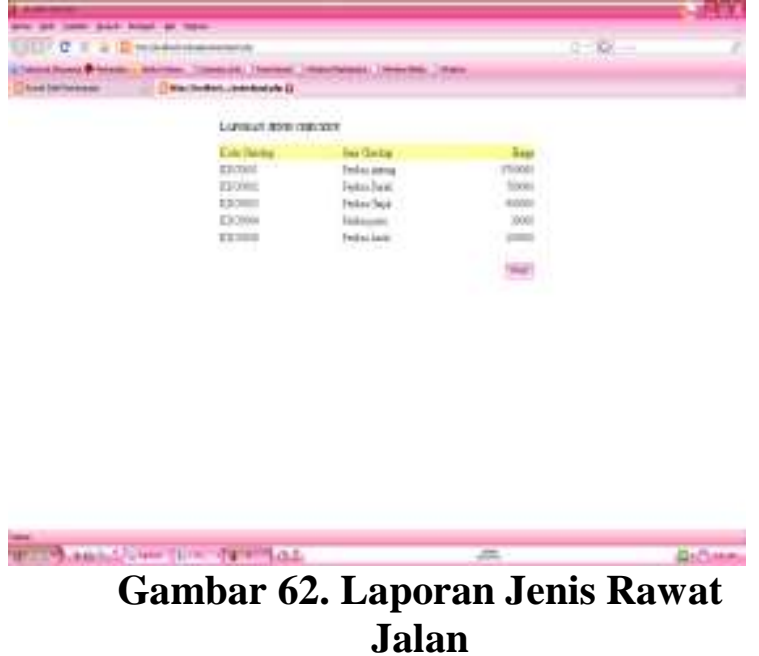

24. Laporan Obat

Halaman ini menampilkan laporan jenis obat untuk manager rumah sakit rawamangun.

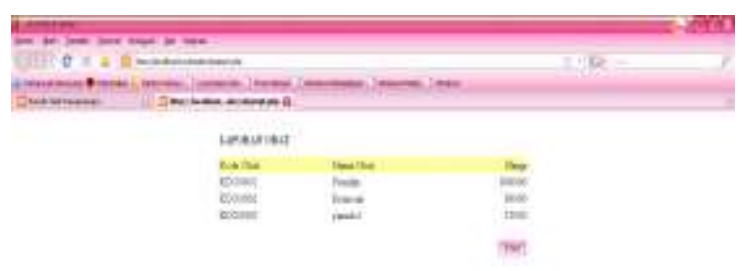

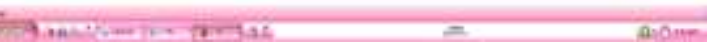

Gambar 63. Laporan Obat

\section{Laporan Jadwal Dokter}

Halaman ini menampilkan laporan jadwal dokter untuk manager rumah sakit rawamangun.
} 


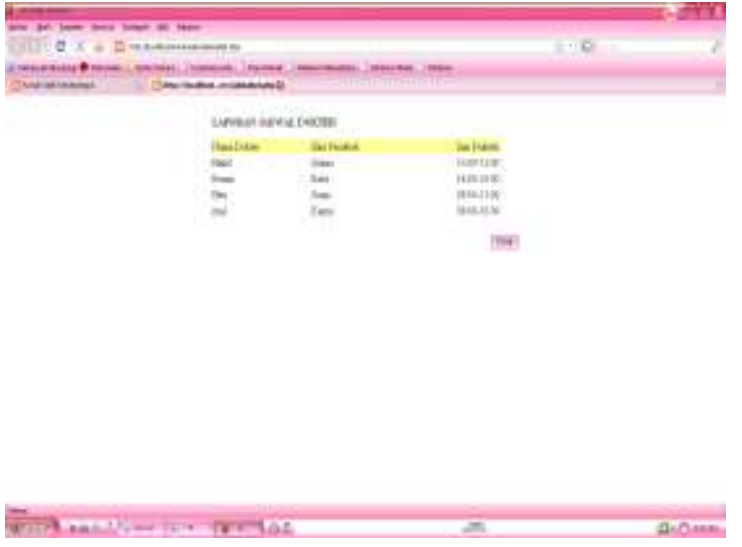

Gambar 64. Laporan Jadwal Dokter

\section{Laporan Diagnosa}

Halaman ini menampilkan laporan diagnose untuk manager rumah sakit rawamangun.

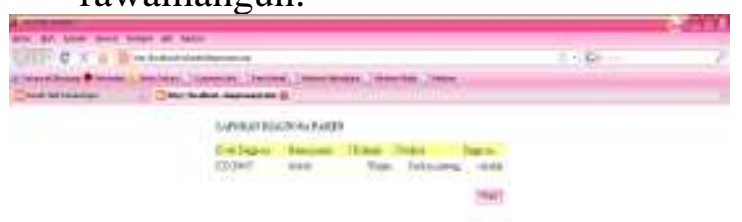

Gambar 65. Laporan Diagnosa

\section{Laporan Pembelian Obat}

Halaman ini menampilkan laporan pembelian obat untuk manager rumah sakit rawamangun.

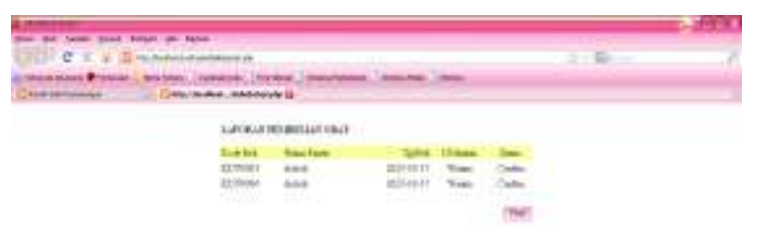

Gambar 66. Laporan Pembelian Obat

\section{Laporan Pembayaran}

Halaman ini menampilkan laporan pembayaran untuk manager rumah sakit rawamangun.

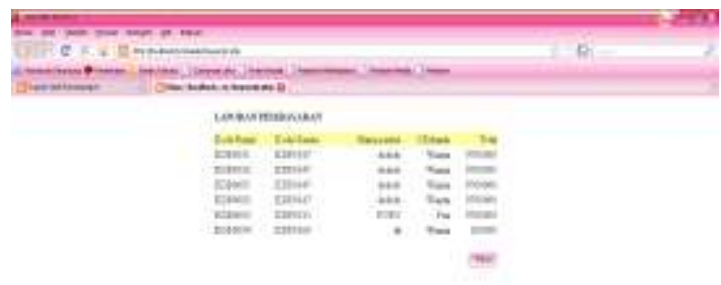

\section{Gambar 67. Laporan Pembayaran}

\section{Laporan Admin}

Halaman ini menampilkan laporan admin untuk manager rumah sakit rawamangun. 


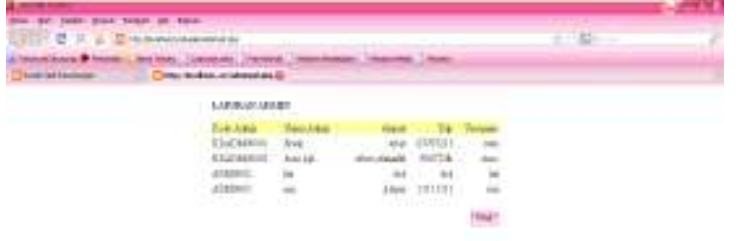

Gambar 68. Laporan Admin

\section{Kesimpulan}

Adapun kesimpulan dari

penelitian ini adalah :

1. Website pendaftaran pasien rawat jalan ini dirancang untuk memenuhi kebutuhan pasien dalam hal pembelajaran dan agar pasien mengerti dalam mencari sumber - sumber informasi tentang rawat jalan berbasis web.

2. Dalam penyampaian informasi tentang rawat jalan agar lebih mudah karena pasien dapat menerapkan langsung rawat jalan berbasis web.

3. Dalam teknologi pemrograman aplikasi berbasis web yang telah dikembangkan, PHP dapat dijadikan sebagai salah satu pilihan utama dalam pembuatan aplikasi berbasis web karena keunggulannya dan kemudahan dalam pemakaian.

4. MySQL sebagai server database merupakan database yang terbaik karena memiliki kelebihan yang sangat baik di antaranya adalah kestabilannya.

5. Aplikasi web yang telah dibuat hendaknya dioperasikan secara baik dan benar untuk mencapai tujuan yang diharapkan.
6. Untuk meningkatkan kinerja serta untuk mengembangkan aplikasi ini maka sebaiknya diadakan pengembangan aplikasi mulai dari tampilan halaman web sampai dengan maintenacenya.

\section{DAFTAR PUSTAKA}

[1] Munawar, 2005. Pemodelan Visual dengan UML. Jakarta. Garaha Ilmu.

[2] Nugroho, Bunafit, 2007. Trik dan Rahasia Mmebuat Aplikasi Web dengan PHP. Yogyakarta: Gaya Media Jogjakarta.

[3] 2008. Latihan Membuat Aplikasi Web PHP dan MySQL dengan Dreamweaver MX $(6,7,2004)$ dan 8. Yogyakarta: Gaya Media Jogjakarta.

[4] Sukarno, Haris, 2006.Membangun Website Dinamis Interaktif dengan PHP-MySQL (Windows \& Linux). Jakarta: Eksa Media.

[5] Gunawan, Wahyu. Kebut Sehari Jadi Master PHP. Yogyakarta: Genius Publisher, 2010.

[6] Jayan. Desain Situs Keren. Palembang. Maxikom, 2008.

[7] Betha, Sidik. Pemograman Web dengan PHP. Bandung : Informatika, 2006

[8] Djon Irwanto, 2006. Perancangan Object Oriented Software dengan UML. ANDI Yogyakarta. 
[9]Lukmanul Hakim, 2008. Membongkar Trik Rahasia Para Master PHP. Lokomedia, 2008.

[10] Firdaus, 2007. 7 Jam Belajar Interaktif PHP \& MySQL dengan Dreamweaver. Palembang. Maxikom, 2007. 